Article

\title{
Improving the Antioxidant Properties of Calophyllum inophyllum Seed Oil from French Polynesia: Development and Biological Applications of Resinous Ethanol-Soluble Extracts
}

\author{
Mathieu Cassien ${ }^{1,2,3}$, Anne Mercier ${ }^{1}$, Sophie Thétiot-Laurent ${ }^{1}$, , Marcel Culcasi ${ }^{1}$, Emilie Ricquebourg ${ }^{1}(\mathbb{D}$, \\ Alice Asteian ${ }^{1}$, Gaëtan Herbette ${ }^{4}\left(\mathbb{D}\right.$, Jean-Pierre Bianchini ${ }^{2}$, Phila Raharivelomanana ${ }^{2}\left(\mathbb{C}\right.$ and Sylvia Pietri ${ }^{1, *}(\mathbb{C})$ \\ 1 Aix Marseille Univ, CNRS, ICR , UMR 7273, SMBSO, 13397 Marseille , France; \\ mathieu.cassien@univ-amu.fr (M.C.); anne.mercier@univ-amu.fr (A.M.); \\ sophie.thetiot-laurent@univ-amu.fr (S.T.-L.); marcel.culcasi@univ-amu.fr (M.C.); \\ emilie.ricquebourg@laposte.net (E.R.); alice.asteian@gmail.com (A.A.) \\ 2 Univ Polynésie Française, IFREMER, ILM, IRD, EIO UMR 241, 98702 Faa'a Tahiti, French Polynesia; \\ jbianchin1938@gmail.com (J.-P.B.); phila.raharivelomanana@upf.pf (P.R.) \\ Yelen Analytics, 13820 Ensuès-la-Redonne, France \\ 4 Aix Marseille Univ, CNRS, Spectropole, FSCM, 13397 Marseille, France; gaetan.herbette@univ-amu.fr \\ * Correspondence: sylvia.pietri@univ-amu.fr; Tel.: +33-(0)4-91-28-85-79; Fax: +33-(0)4-91-28-87-58
}

Citation: Cassien, M.; Mercier, A.; Thétiot-Laurent, S.; Culcasi, M.; Ricquebourg, E.; Asteian, A.; Herbette, G.; Bianchini, J.-P.; Raharivelomanana, P.; Pietri, S. Improving the Antioxidant Properties of Calophyllum inophyllum Seed Oil from French Polynesia: Development and Biological Applications of Resinous Ethanol-Soluble Extracts. Antioxidants 2021, 10, 199. https:// doi.org/10.3390/antiox10020199

Academic Editor: Giovanna Mobbili Received: 30 December 2020

Accepted: 23 January 2021

Published: 30 January 2021

Publisher's Note: MDPI stays neutral with regard to jurisdictional claims in published maps and institutional affiliations.

Copyright: (c) 2021 by the authors. Licensee MDPI, Basel, Switzerland. This article is an open access article distributed under the terms and conditions of the Creative Commons Attribution (CC BY) license (https:// creativecommons.org/licenses/by/ $4.0 /)$.
Abstract: Tamanu oil from Calophyllum inophyllum L. has long been used in traditional medicine. Ethanol extraction was found the best strategy for recovering bioactive compounds from the resin part of Tamanu oil, yielding two neutral and acidic resins fractions with high phenolics, flavonoids and pyranocoumarins concentrations. A further cascade of LPLC/HPLC separations of neutral and acidic resin fractions allowed identifying fifteen metabolites, and among them, calanolide D and 12-oxocalanolide A (both in neutral fraction) were first identified from a natural source. All these extracts, subfractions and isolated metabolites demonstrated increased free radical scavenging, antioxidant, anti-inflammatory, antimicrobial and antimycobacterial activity compared to Tamanu oil and its de-resinated lipid phase. Overall, these results could promote resinous ethanol-soluble Tamanu oil extracts as a useful multifaceted and renewable medicinal resource.

Keywords: Calophyllum inophyllum L.; Tamanu oil; ethanol-soluble resin extracts; lipophilic antioxidants; phenolics; pyranocoumarins; antimicrobial; anti-inflammatory; UV protection; EPR spin trapping

\section{Introduction}

Calophyllum inophyllum L. (Calophyllaceae) is an evergreen tree distributed in tropical areas of Africa, America, Asia and Pacific Islands. Many pharmacological properties from different parts of $C$. inophyllum such as leaves, bark and oil have been reported in traditional folk medicines, with variations in local uses [1]. Leaves are generally used as decoctions, to treat dermatoses or eye ailments, and the bark juice has purgative properties. Expressed from the seeds, C. inophyllum oil is widely used as a natural antiseptic and anti-inflammatory agent and for treating venous ulcers, rheumatisms and wounds [2]. Several contributions to the knowledge of the mechanisms of action of C. inophyllum oil have been reported, and its anti-inflammatory, anti-microbial and cytoprotective properties have been evidenced in cell models [3,4]. C. inophyllum oil is essentially composed of lipids (about 70-80\%) [5], and of a resinous part gathering the main bioactive compounds (about 15-20\%), such as sterols, coumarins, triterpenoids and flavonoids [1,2]. In recent decades, a series of pyranocoumarins in seeds or leaves of Calophyllum genus plants have been identified, belonging to the calanolide, inophyllum or cordatolide series [6-9]; e.g., calanolides A, B and pseudocalanolides C and D are found in C. lanigerum [6]. In the C. inophyllum oil found worldwide, several 4-phenylcoumarin derivatives were isolated, such as callophylolide and inophyllolides, including inophyllums B, C, E and P [7,8,10,11]. 
Remarkable biochemical and pharmacological properties have been reported for some of these constituents; e.g., (+)-calanolide $\mathrm{A}$ is a non-nucleosidic reverse transcriptase inhibitor [9] exhibiting protection against Mycobacterium tuberculosis [12]. Callophylolide and inophyllums $C$ and $E$ were found to exhibit antimicrobial and cytotoxic activities [11] and preventive action against cancer induction by the Epstein-Barr virus [13]. Calophyllic and isocalophyllic acids, found in the $C$. inophyllum leaves, demonstrated antidyslipidemic and weak antioxidant activities [14].

In French Polynesia, C. inophyllum is locally called Tamanu and has a great heritage interest as a sacred tree. Tamanu oil (TO), the non-edible cold-pressed oil from dried nuts is widely used in traditional medicine and as a component for cosmetics commercialized in French Polynesia or for exportation. Recently, remarkable wound healing and antimicrobial properties of crude C. inophyllum oils from several origins have been reported, with variations depending on their variable compositions [15]. Other data revealed a strong enhancement of metabolic processes involved in cell adhesion and proliferation in keratinocytes upon treatment with TO emulsified with olive oil [16].

However, despite its great potential interest, major drawbacks of using $\mathrm{TO}$ as a raw material for therapeutic and cosmetic applications arise both from a very high lipophilicity and the weak amount of potentially bioactive compounds contained in the minor soluble phase [17]. This latter issue could be solved by ethanol extraction, a process that would allow recovering the largest amount of TO metabolites. To illustrate, three new pyranocoumarins with an unprecedented C-4 substituent, namely, tamanolide and tamanolides D and P [18], and two other new neoflavonoids, i.e., tamanolides E1 and E2 [19], were recently characterized from this ethanolic resin fraction. In line with the above, ethanolic extracts of $C$. inophyllum seed exhibited antiarthritic activities in rats, suggesting that a significant amount of phytoconstituents are bioavailable [20].

In our continuous interest in developing easy handling pharmaceutical preparations from natural sources of great economic potential [21,22], the purpose of the present study was (i) to prepare novel soluble TO extracts and subfractions with enhanced inhibition properties toward a host of reactive oxygen species (ROS); (ii) to screen them for their antioxidant, anti-inflammatory and antimicrobial properties using a battery of physicochemical and biochemical tests; and (iii) to further isolate and characterize in these TO fractions those compounds showing the greatest potential for biological applications.

\section{Materials and Methods}

\subsection{Extraction and Fractionation of Tamanu Oil and Resins}

\subsubsection{Chemicals and Instrumentation}

Folin-Ciocalteu reagent, gallic acid, rutin and all other chemicals and solvents were of analytical grade from Acros Organics-Fisher Scientific (Illkirch, France) or Sigma-Aldrich (Saint-Quentin Fallavier, France). Deuterated solvents were purchased from Euriso-Top (Gif-sur-Yvette, France), and TLC silica gel plates were purchased from Merck (Darmstadt, Germany). ${ }^{1} \mathrm{H}$ NMR spectra were recorded in $\mathrm{CDCl}_{3}$ on a Bruker Avance DRX 500 spectrometer operating at $500 \mathrm{MHz}$. Chemical shifts $(\delta)$ are reported in ppm relative to internal tetramethylsilane (TMS). Coupling constants are expressed in Hertz (Hz). Splitting patterns are as follows: $\mathrm{s}=$ singlet; $\mathrm{d}=$ doublet; $\mathrm{dd}=$ doublet of doublets; $\mathrm{t}=$ triplet; $\mathrm{q}=$ quadruplet; $\mathrm{dq}=$ doublet of quadruplets; $\mathrm{tq}=$ triplet of quadruplets; sext = sextet; $\mathrm{m}=$ multiplet; $\mathrm{b}=$ broad peak. Optical rotations were measured using a SCP 200 polarimeter (Anton Paar; Courtaboeuf, France) with a 0.2-cm path length. Low-Pressure Liquid Chromatography (LPLC) was performed on a glass chromatography column $(600 \mathrm{~mm} \times 50 \mathrm{~mm}, 1 \mathrm{~L})$ filled with silica gel $60\left(\mathrm{SiO}_{2}\right.$, Prolabo, Fontenay-sous-Bois, France), connected to a low-pressure pump operating at a flow-rate of $6 \mathrm{~mL} / \mathrm{min}$. Preparative HPLC was performed on an Agilent HP 1100 Series system (Massy, France) equipped with a quaternary pump (G 1311A, Agilent), a standard autosampler (ALS G1313A, Agilent), silica columns $(250 \times 10 \mathrm{~mm}$ i.d., $10 \mu \mathrm{m}$, LiChrospher 100 DIOL, Merck, Darmstadt, Germany), at a flow-rate of $10 \mathrm{~mL} / \mathrm{min}$ and monitored by a UV-DAD diode-array detector (G1315A, Agilent) using a preparative 
cell (3 $\mathrm{mm}$ path) at a defined detection wavelength. Spectrophotometric measurements were performed on an Infinite M200 microplate reader (TECAN infinite M200, Switzerland). Mass spectrometry (MS) analyses were carried out using a 3200 QTRAP mass spectrometer (Applied Biosystems SCIEX).

2.1.2. Extraction of Ethanol-Soluble Resins from Tamanu Oil, Separation of Neutral and Acidic Fractions and Determination of Total Phenolic Content (TPC) and Total Flavonoid Content (TFC)

The whole process is shown in Scheme 1. Mature seeds of C. inophyllum were collected on the seashore of Huahine Island in French Polynesia, from September to October 2014, and manually crushed. The almonds were sun-dried for two weeks, and TO was obtained by cold pressing, followed by filtration to remove residual water. The recovered oil (1800 g) was first extracted with $70 \mathrm{~mL}$ of $96 \% v / v$ ethanol to remove a gummy dark green solid. The filtrate was then extracted with ethanol $(3 \times 1 \mathrm{~L})$, and the solvent was removed under vacuum to afford the ethanol-soluble extract (EtTO, $285 \mathrm{~g}$ ) as a brown resin. Residual de-resinated Tamanu oil (DTO) was kept for further experiments. Afterwards, EtTO (238 g) was dissolved in diethyl ether $(2 \mathrm{~L})$ and extracted with aqueous $\mathrm{NaOH}(10 \% v / v)$ until $\mathrm{pH}$ 10. The resulting organic layer was washed with distilled water until neutrality, dried over anhydrous $\mathrm{MgSO}_{4}$, filtered and concentrated to give a neutral Tamanu resin fraction (NTR, $119 \mathrm{~g}$ ). The aqueous layer was carefully acidified until $\mathrm{pH} 4$ with $\mathrm{H}_{2} \mathrm{SO}_{4}(1 \mathrm{M})$ under cooling, extracted with diethyl ether $(3 \times 100 \mathrm{~mL})$, dried over anhydrous $\mathrm{MgSO}_{4}$, filtered and concentrated to give the acidic Tamanu resin fraction (ATR, $115 \mathrm{~g}$ ).

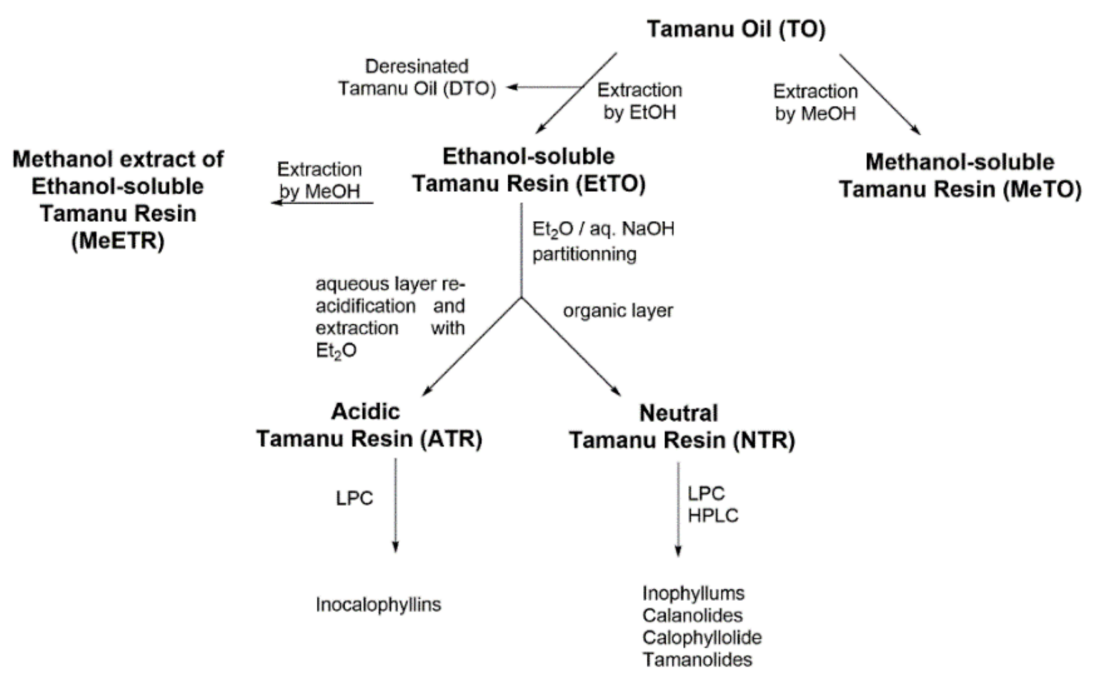

Scheme 1. Extraction and fractionation process of Tamanu oil (TO) into methanol soluble (MeTO) and ethanol-soluble (EtTO) resins and subsequent neutral (NTR), acidic (ATR) and methanolic (MeETR) fractions preparation.

TPC and TFC of TO and extracts were assessed using the Folin-Ciocalteu reagent and aluminium chloride complexation, respectively [23]. TPC was evaluated using a gallic acid calibration curve in methanol and expressed as milligrams of gallic acid equivalents (GAE) per gram of extract weight. TFC was evaluated using a rutin calibration curve in ethanol and expressed as milligrams of rutin equivalents (RUE) per gram of extract weight.

\subsubsection{Preparation of TO and EtTO Methanol Soluble Extracts}

TO or EtTO were dissolved in methanol $(1 \mathrm{~g} / \mathrm{mL})$ under agitation for $2 \mathrm{~h}$ at $22^{\circ} \mathrm{C}$, and vortexed for $4 \mathrm{~min}$. The upper layers were collected, and the extraction process was performed two more times. Combined extracts from TO and EtTO were centrifuged (3000 rpm, $10 \mathrm{~min}, 4^{\circ} \mathrm{C}$ ) and the supernatants were evaporated until dryness to afford the methanol soluble Tamanu oil (MeTO; $18.2 \% w / w$ yield) and methanol soluble resin 
(MeETR, 25.3\% $w / w$ yield) extracts, respectively. TPC and TFC contents were determined for each extract as described above.

\subsubsection{LPLC Analysis of NTR and ATR Fractions}

NTR $(10 \mathrm{~g})$ in $50 \mathrm{~mL}$ dichloromethane was mixed with $50 \mathrm{~g}$ silica gel 60 . After solvent removal at room temperature, the impregnated silica was poured onto a glass column pre-filled with silica gel in $n$-hexane. LPLC was performed starting with $n$-hexane followed by the following step-gradient: $n$-hexane/AcOEt (10/90, 15/85, 20/80, 30/70, 40/60 and $50 / 50 v / v, 1 \mathrm{~L}$ each). Effluent fractions were monitored by thin-layer chromatography (TLC) and gathering similar fractions yielded a total of ten NTR subfractions termed as NTR I-NTR X. The whole process was repeated to allow a total amount of $70 \mathrm{~g}$ of NTR to be treated. A similar procedure was applied to ATR $(6 \times 10 \mathrm{~g})$ using the step-gradient: $n$-hexane/AcOEt (10/90, 20/80, 40/60, and 80/20 v/v, $1 \mathrm{~L}$ each). From TLC monitoring, a total of four ATR subfractions termed as ATR I-ATR IV were then obtained.

\subsubsection{HPLC Separation of NTR and ATR Subfractions}

HPLC separation and subfractions preparation was achieved according to previous procedures [18]. Six subfractions $(50 \mathrm{mg})$ with moderate polarity and giving a blue spot with the vanillin $/ \mathrm{H}_{2} \mathrm{SO}_{4}$ TLC stain (fractions NTR IV-VII and ATR II, III; TLC: $0.3<\mathrm{R}_{\mathrm{f}}<0.6$, $n$-hexane-AcOEt, $7 / 3, v / v$ ) were dissolved in $5 \mathrm{~mL}$ of a mixture of $n$-hexane/isopropanol $(3 / 97, v / v)$. After filtration, the residues were fractionated by preparative HPLC using $n$-hexane/isopropanol $(3 / 97, v / v)$ in isocratic conditions at a flow rate of $10 \mathrm{~mL} / \mathrm{min}$, with UV/Vis monitoring at $300 \mathrm{~nm}$. The major compounds were manually collected and concentrated under vacuum. Fifteen phytoconstituents (pure compounds or mixtures) were then identified by comparing their NMR $\left({ }^{1} \mathrm{H}\right.$ and $\left.{ }^{13} \mathrm{C}\right), \mathrm{MS}$ and absorption spectra with literature data. The recovered compounds are given as follows (LPLC fraction/HPLC peak, mg): inophyllum P (NTR IV/2, $20.7 \mathrm{mg}$ ); tamanolide P (NTR IV/3, $56.4 \mathrm{mg}$ in mixture with inophyllum $\mathrm{P}$ and calanolide $\mathrm{B}$, this fraction was termed as Fraction $\mathrm{P}$ ); calophyllolide (NTR V/3, $26.2 \mathrm{mg}$ ); calanolide GUT 70 (NTR V/5, $32.9 \mathrm{mg}$ ); inophyllum C (NTR VI/1, $38.8 \mathrm{mg}$ and NTR VII/5, $14.9 \mathrm{mg}$ ); 12-oxocalanolide A (NTR VI/2, 7.0 mg); inophyllum E (NTR VI/3, $19.4 \mathrm{mg}$ ); tamanolide D (NTR VI/4, $26.3 \mathrm{mg}$ and inophyllum D and epi-calanolide $C$ as a mixture, termed as Fraction D); tamanolide (NTR V /4, 28.6 mg); calanolide D (NTR VII/1, $10.0 \mathrm{mg}$ ); calanolide A (NTR VII/2, $7.0 \mathrm{mg}$ ); and inocalophyllin B (ATR II/1, $40.1 \mathrm{mg}$ ). Further separation on fraction NTR VI/4, driven as reported [18,24], yielded tamanolide D $(1.1 \mathrm{mg})$ with a HPLC purity $>95 \%$. Analytical HPLC controls were carried out on three different systems using either silica (n-hexane/isopropanol, 93/7, $v / v$ or $n$-hexane/AcOEt, 78/22, $v / v$ ) or reversed-phase $\left(\mathrm{C}_{18}\right)$ (acetonitrile/water/TFA, $85 / 15 / 0.1 \mathrm{v} / \mathrm{v} / \mathrm{v}$ ) columns.

These eleven metabolites showed HPLC purity > 95\%, and their ${ }^{1} \mathrm{H}-$ (see below), ${ }^{13} \mathrm{C}-\mathrm{NMR}$ and MS spectra are shown in Supplementary Information.

The composition of Fraction P was determined by HPLC as follows: inophyllum P $(70 \%)$, tamanolide P $(20 \%)$, and calanolide B $(10 \%)$. Similarly the composition of Fraction D was determined as follows: tamanolide D (40\%), inophyllum D (40\%), and epi-calanolide C (20\%). For both mixtures, ${ }^{1}$ H-NMR spectra are shown in Supplementary Information.

Nine of the isolated derivatives and Fraction $\mathrm{P}$ were obtained in reasonable amounts for further use in antioxidant and biological studies.

\subsubsection{UV, ${ }^{1} \mathrm{H}-\mathrm{NMR}$ and Optical Characteristics of Isolated TO Metabolites}

Inocalophyllin B. UV ( $n$-hexane/AcOEt, 78/22, $v / v): \lambda_{\max }(\mathrm{nm}) 312,282 .{ }^{1} \mathrm{H}-\mathrm{NMR}$ $\left(\mathrm{CDCl}_{3}\right): \delta 0.86(\mathrm{t}, J=7.3 \mathrm{~Hz}, 3 \mathrm{H}, \mathrm{H}-15), 1.14(\mathrm{~d}, J=7.0 \mathrm{~Hz}, 3 \mathrm{H}, \mathrm{H}-22), 1.20(\mathrm{~m}, J=7.0 \mathrm{~Hz}$, 2H, H-14), 1.53 (d, J = 7.0 Hz, 3H, H-21), 1.53 (bs, 3H, H-29), 1.54 (bs, 3H, H-19), 1.56 (bs, 3H, H-20), 1.58 (bs, 2H, H-32), 1.64 (bs, 3H, H-28), 1.76-1.82 (m, 2H, H-13), 1.87 (dd, $J=10.5$ and $7.6 \mathrm{~Hz}, 1 \mathrm{H}, \mathrm{H}-25), 1.95(\mathrm{~m}, 1 \mathrm{H}, \mathrm{H}-24), 1.99(\mathrm{~d}, J=12.7 \mathrm{~Hz}, 1 \mathrm{H}, \mathrm{H}-23), 2.12(\mathrm{dd}, J=12.7$ and $1.0 \mathrm{~Hz}, 1 \mathrm{H}, \mathrm{H}-23), 2.45$ (bdd, $J=13.5$ and $8.5 \mathrm{~Hz}, 1 \mathrm{H}, \mathrm{H}-8), 2.48(\mathrm{dq}, J=13.5$ and $6.6 \mathrm{~Hz}, 1 \mathrm{H}$, 
H-11), 2.61 (bdd, $J=13.5$ and $6.8 \mathrm{~Hz}, 1 \mathrm{H}, \mathrm{H}-8), 2.69(\mathrm{dd}, J=15.6$ and $6.4 \mathrm{~Hz}, 1 \mathrm{H}, \mathrm{H}-3), 2.85$ $(\mathrm{dd}, J=15.6$ and $8.3 \mathrm{~Hz}, 1 \mathrm{H}, \mathrm{H}-3), 3.47(\mathrm{~m}, 1 \mathrm{H}, \mathrm{H}-4), 4.08(\mathrm{dq}, J=13.5$ and $6.4 \mathrm{~Hz}, 1 \mathrm{H}, \mathrm{H}-10)$, $4.53(\mathrm{dq}, J=10.3$ and $1.4 \mathrm{~Hz}, 1 \mathrm{H}, \mathrm{H}-31), 4.56(\mathrm{dq}, J=12.3$ and $1.4 \mathrm{~Hz}, 1 \mathrm{H}, \mathrm{H}-31), 4.70$ (tq, $J=6.9$ and $1.4 \mathrm{~Hz}, 1 \mathrm{H}, \mathrm{H}-7), 4.89(\mathrm{~m}, J=6.8$ and $1.4 \mathrm{~Hz}, 1 \mathrm{H}, \mathrm{H}-26), 12.32(\mathrm{~s}, 1 \mathrm{H}, 12 \mathrm{~b}-\mathrm{OH})$. Spectroscopic data (Figures S1 and S14) were in good agreement with the literature [25].

Inophyllum C. UV (n-hexane/AcOEt, 78/22, v/v): $\lambda_{\max }(\mathrm{nm}) 300,268,258 .{ }^{1} \mathrm{H}-\mathrm{NMR}$ $\left(\mathrm{CDCl}_{3}\right): \delta 0.95$ (s, 3H, H-20), 0.96 (s, 3H, H-19), 1.26 (d, J = 6.9 Hz, 3H, H-22), 1.56 (d, $J=6.2 \mathrm{~Hz}, 3 \mathrm{H}, \mathrm{H}-21), 2.60(\mathrm{dq}, J=11.1$ and $6.9 \mathrm{~Hz}, 1 \mathrm{H}, \mathrm{H}-11), 4.33(\mathrm{dq}, J=11.1$ and $6.3 \mathrm{~Hz}$, 1H, H-10), 5.43 (d, J = 10.1 Hz, 1H, H-7), 6.07 (s, 1H, H-3), 6.56 (d, J = $10.1 \mathrm{~Hz}, 1 \mathrm{H}, \mathrm{H}-8$ ), $7.40\left(\mathrm{~m}, 5 \mathrm{H}, \mathrm{H}_{\text {phenyl }}\right)$. Spectroscopic data (Figure S2) were in good agreement with the literature [26].

Inophyllum D. ${ }^{1} \mathrm{H}-\mathrm{NMR}\left(\mathrm{CDCl}_{3}\right): \delta 0.79(\mathrm{~d}, J=7.3 \mathrm{~Hz}, 3 \mathrm{H}, \mathrm{H}-22), 0.93(\mathrm{~s}, 6 \mathrm{H}, \mathrm{H}-19$ and $\mathrm{H}-20), 1.42(\mathrm{~d}, J=6.5 \mathrm{~Hz}, 3 \mathrm{H}, \mathrm{H}-21), 2.03$ (qt, $J=7.2$ and $2.1 \mathrm{~Hz}, 1 \mathrm{H}, \mathrm{H}-11), 4.54$ (qd, $J=6.6$ and $2.2 \mathrm{~Hz}, 1 \mathrm{H}, \mathrm{H}-10), 4.92(\mathrm{~d}, J=2.2 \mathrm{~Hz}, 1 \mathrm{H}, \mathrm{H}-12), 5.35(\mathrm{~d}, J=10.0 \mathrm{~Hz}, 1 \mathrm{H}, \mathrm{H}-7)$, 5.96 (s, 1H, H-3), 6.55 (d, J = 10.1 Hz, 1H, H-8), 7.23 (m, 2H, $\mathrm{H}_{\text {phenyl }}$ ), 7,35 (m, 3H, $\mathrm{H}_{\text {phenyl }}$ ). Spectroscopic data (Figure S12) were in good agreement with the literature [10].

Inophyllum E. UV (n-hexane/AcOEt, 78/22, v/v): $\lambda_{\max }(\mathrm{nm}) 300,268,258 .{ }^{1} \mathrm{H}-\mathrm{NMR}$ $\left(\mathrm{CDCl}_{3}\right): \delta 0.97$ (s, 3H, H-20), 0.99 (s, 3H, H-19), 1.20 (d, J = 7.2 Hz, 3H, H-22), 1.44 (d, $J=6.6 \mathrm{~Hz}, 3 \mathrm{H}, \mathrm{H}-21), 2.73(\mathrm{dq}, J=7.2$ and $3.5 \mathrm{~Hz}, 1 \mathrm{H}, \mathrm{H}-11), 4.74(\mathrm{dq}, J=6.5$ and $3.4 \mathrm{~Hz}$, $1 \mathrm{H}, \mathrm{H}-10), 5.43$ (d, J = 10.1 Hz, 1H, H-7), 6.07 (s, 1H, H-3), 6.57 (d, J = $10.1 \mathrm{~Hz}, 1 \mathrm{H}, \mathrm{H}-8$ ), $7.32\left(\mathrm{~m}, 5 \mathrm{H}, \mathrm{H}_{\text {phenyl }}\right)$. Spectroscopic data (Figure S3) were in good agreement with the literature [26].

Inophyllum P. UV (n-hexane/AcOEt, 78/22, v/v): $\lambda_{\max }(\mathrm{nm}) 335,288,278 .[\alpha]^{\mathrm{D}}{ }_{25}=+19.8^{\circ}$ (c 0.8, $\left.\mathrm{CHCl}_{3}\right) .{ }^{1} \mathrm{H}-\mathrm{NMR}\left(\mathrm{CDCl}_{3}\right): \delta 0.95$ (s, 3H, H-19), 0.95 (s, 3H, H-20), 1.18 (d, J = 7.0 Hz, $3 \mathrm{H}, \mathrm{H}-22), 1.45(\mathrm{~d}, J=6.3 \mathrm{~Hz}, 3 \mathrm{H}, \mathrm{H}-21), 1.78(\mathrm{ddq}, J=10.5,3.4$ and $7.0 \mathrm{~Hz}, 1 \mathrm{H}, \mathrm{H}-11), 4.30(\mathrm{dq}$, $J=10.7$ and $6.3 \mathrm{~Hz}, 1 \mathrm{H}, \mathrm{H}-10), 5.38(\mathrm{~d}, J=10.0 \mathrm{~Hz}, 1 \mathrm{H}, \mathrm{H}-7), 5.05(\mathrm{~d}, J=3.3 \mathrm{~Hz}, 1 \mathrm{H}, \mathrm{H}-12), 5.98$ (s, 1H, H-3), 6.55 (d, J = 10.0 Hz, 1H, H-8), 7.3 (m, 5H, $\mathrm{H}_{\text {phenyl }}$ ). Spectroscopic data (Figure S4) were in good agreement with the literature [26].

Calophyllolide. UV (n-hexane/AcOEt, 78/22, v/v): $\lambda_{\max }(\mathrm{nm}) 292,270 .{ }^{1} \mathrm{H}-\mathrm{NMR}$ $\left(\mathrm{CDCl}_{3}\right): \delta 0.98(\mathrm{~s}, 6 \mathrm{H}, \mathrm{H}-19$ and H-20), $1.91(\mathrm{~d}, \mathrm{~J}=7.0 \mathrm{~Hz}, 3 \mathrm{H}, \mathrm{H}-21), 2.02(\mathrm{~s}, 3 \mathrm{H}, \mathrm{H}-22), 3.77$ (s, 3H, H-23), 5.49 (d, J = 10.0 Hz, 1H, H-7), 6.03 (s, 1H, H-3), 6.47 (d, J = 10.0 Hz, 1H, H-8), $6.58(\mathrm{bq}, J=7.0,1 \mathrm{H}, \mathrm{H}-10), 7.33\left(\mathrm{~m}, 5 \mathrm{H}, \mathrm{H}_{\text {phenyl }}\right)$. Spectroscopic data (Figure S5) were in good agreement with the literature [26].

12-Oxocalanolide A. UV (n-hexane/AcOEt, 78/22, v/v): $\lambda_{\max }(\mathrm{nm}) 294,266,258 .{ }^{1} \mathrm{H}$ $\operatorname{NMR}\left(\mathrm{CDCl}_{3}\right): \delta 1.02(\mathrm{t}, J=7.5 \mathrm{~Hz}, 3 \mathrm{H}, \mathrm{H}-15), 1.21(\mathrm{~d}, J=6.9 \mathrm{~Hz}, 1 \mathrm{H}, \mathrm{H}-19), 1.52(\mathrm{~s}, 3 \mathrm{H}$, H-17), 1.54 (d, J = 6.3 Hz, 3H, H-18), 1.55 (s, 3H, H-16), 1.64 (sext, J = $7.8 \mathrm{~Hz}, 2 \mathrm{H}, \mathrm{H}-14$ ), $2.55(\mathrm{dq}, J=11.1$ and $6.9 \mathrm{~Hz}, 1 \mathrm{H}, \mathrm{H}-11), 2.88(\mathrm{~m}, 2 \mathrm{H}, \mathrm{H}-13), 4.29(\mathrm{dq}, J=11.1$ and $6.3 \mathrm{~Hz}$, 1H, H-10), 5.59 (d, J = 10.0 Hz, 1H, H-7), 6.04 (bs, 1H, H-3), 6.65 (d, J = 10.0 Hz, 1H, H-8). Spectroscopic data (Figure S6) were in good agreement with the literature [27].

Epi-calanolide C. ${ }^{1} \mathrm{H}-\mathrm{NMR}\left(\mathrm{CDCl}_{3}\right): \delta(\mathrm{d}, J=7.1 \mathrm{~Hz}, 3 \mathrm{H}, \mathrm{H}-22), 1.03(\mathrm{t}, J=7.3 \mathrm{~Hz}, 3 \mathrm{H}$, H-15), 1.42 (d, J = 6.5 Hz, 3H, H-21), 1.48 (s, 6H, H-19 and H-20), 1.65 (m, 2H, H-14), 2.03 (qt, $J=7.2$ and $2.1 \mathrm{~Hz}, 1 \mathrm{H}, \mathrm{H}-11), 2.89(\mathrm{~m}, 2 \mathrm{H}, \mathrm{H}-13), 4.54(\mathrm{qd}, J=6.6$ and $2.2 \mathrm{~Hz}, 1 \mathrm{H}, \mathrm{H}-10)$, $4.86(\mathrm{~d}, J=2.1 \mathrm{~Hz}, 1 \mathrm{H}, \mathrm{H}-12), 5.53(\mathrm{~d}, J=10.0 \mathrm{~Hz}, 1 \mathrm{H}, \mathrm{H}-7), 5.95$ (t, J = 0.8 Hz, 1H, H-3), 6.65 $(\mathrm{d}, J=10.0 \mathrm{~Hz}, 1 \mathrm{H}, \mathrm{H}-8)$. Spectroscopic data (Figure S12) were in good agreement with the literature [28].

Calanolide A. UV ( $n$-hexane/AcOEt, 78/22, v/v): $\lambda_{\max }(\mathrm{nm}) 258,266 .{ }^{1} \mathrm{H}-\mathrm{NMR}\left(\mathrm{CDCl}_{3}\right)$ : $\delta 1.03(\mathrm{t}, J=7.3 \mathrm{~Hz}, 3 \mathrm{H}, \mathrm{H}-15), 1.15(\mathrm{~d}, J=6.8 \mathrm{~Hz}, 3 \mathrm{H}, \mathrm{H}-19), 1.46(\mathrm{~d}, J=6.4 \mathrm{~Hz}, 3 \mathrm{H}, \mathrm{H}-18)$, 1.46 (s, 3H, H-17), 1.51 (s, 3H, H-16), 1.66 (m, 2H, H-14), 1.93 (ddq, $J=9.0,7.8$ and 6.8 Hz, 1H, H-11), 2.89 (m, 2H, H-13), 3.60 (bs, 1H, -OH), $3.92(\mathrm{dq}, J=9.0$ and $6.4 \mathrm{~Hz}, 1 \mathrm{H}, \mathrm{H}-10)$, 4.74 (d, $J=7.8 \mathrm{~Hz}, 1 \mathrm{H}, \mathrm{H}-12), 5.54$ (d, $J=10.0 \mathrm{~Hz}, 1 \mathrm{H}, \mathrm{H}-7), 5.94$ (bs, 1H, H-3), 6.62 (d, $J=10.0 \mathrm{~Hz}, 1 \mathrm{H}, \mathrm{H}-8)$. Spectroscopic data (Figures S7 and S15) were in good agreement with the literature [26].

Calanolide B. ${ }^{1} \mathrm{H}-\mathrm{NMR}\left(\mathrm{CDCl}_{3}\right): \delta 1.02(\mathrm{t}, J=7.3 \mathrm{~Hz}, 3 \mathrm{H}, \mathrm{H}-15), 1.15(\mathrm{~d}, J=7.1 \mathrm{~Hz}, 3 \mathrm{H}$, H-19), 1.48 (d, J = 6.4 Hz, 3H, H-18), 1.48 (s, 6H, H-16 and H-17), 1.64 (sext, J = 7.3 Hz, 2H, 
$\mathrm{H}-14), 1.73$ (ddq, $J=10.5,6.4$ and $2.8 \mathrm{~Hz}, 1 \mathrm{H}, \mathrm{H}-11), 2.78$ (bs, 1H, -OH), 2.87 (m, 2H, H-13), $4.25(\mathrm{dq}, J=10.5$ and $6.4 \mathrm{~Hz}, 1 \mathrm{H}, \mathrm{H}-10), 4.96(\mathrm{~d}, J=2.8 \mathrm{~Hz}, 1 \mathrm{H}, \mathrm{H}-12), 5.52(\mathrm{~d}, J=9.9 \mathrm{~Hz}$, 1H, H-7), 5.93 (bs, 1H, H-3), 6.63 (d, J = 9.9 Hz, 1H, H-8). Spectroscopic data (Figure S13) were in good agreement with the literature [26].

Calanolide D. UV ( $n$-hexane/AcOEt, 78/22,v/v): $\lambda_{\max }(\mathrm{nm}) 294,266,258 .{ }^{1} \mathrm{H}-\mathrm{NMR}$ $\left(\mathrm{CDCl}_{3}\right): \delta 1.02(\mathrm{t}, J=7.3 \mathrm{~Hz}, 3 \mathrm{H}, \mathrm{H}-15), 1.15(\mathrm{~d}, J=7.2 \mathrm{~Hz}, 3 \mathrm{H}, \mathrm{H}-19), 1.41(\mathrm{~d}, J=6.6 \mathrm{~Hz}, 3 \mathrm{H}$, $\mathrm{H}-18), 1.53$ (s, 3H, H-17), 1.54 (s, 3H, H-16), 1.64 (m, 2H, H-14), 2.68 (dq, J = 3.4 and 7.2 Hz, 1H, H-11), 2.88 (m, 2H, H-13), 4.69 (dq, $J=3.4$ and $6.6 \mathrm{~Hz}, 1 \mathrm{H}, \mathrm{H}-10), 5.59$ (d, $J=10.1 \mathrm{~Hz}$, 1H, H-7), 6.04 (bs, 1H, H-3), 6.65 (d, $J=10.0 \mathrm{~Hz}, 1 \mathrm{H}, \mathrm{H}-8)$. Spectroscopic data (Figure S8) were in good agreement with the literature [29].

Calanolide GUT 70. UV (n-hexane/AcOEt, 78/22, v/v): $\lambda_{\max }(\mathrm{nm}) 292,272 .{ }^{1} \mathrm{H}-\mathrm{NMR}$ $\left(\mathrm{CDCl}_{3}\right): \delta 1.05(\mathrm{t}, J=7.3 \mathrm{~Hz}, 3 \mathrm{H}, \mathrm{H}-15), 1.53(\mathrm{~s}, \mathrm{H}-16,6 \mathrm{H}, \mathrm{H}-17), 1.60$ (m, 2H, H-14), 1.86 (d, J = 7.0 Hz, H3H,-18), 1.98 (s, 3H, H-19), 2.81 (t, J = 7.6 Hz, 2H, H-13), 3.76 (s, 3H, H-20), $5.66(\mathrm{~d}, J=10.0 \mathrm{~Hz}, 1 \mathrm{H}, \mathrm{H}-7), 6.01$ (s, 1H, H-3), 6.49 (q, J = 6.9 Hz, 1H, H-10), 6.55 (d, $J=10.0 \mathrm{~Hz}, 1 \mathrm{H}, \mathrm{H}-8)$. Spectroscopic data (Figures S9 and S16) were in good agreement with the literature [26].

Tamanolide. UV (n-hexane/AcOEt, 78/22, v/v): $\lambda_{\max }(\mathrm{nm}) 292,266 .[\alpha]^{\mathrm{D}}{ }_{25}=-3.3^{\circ}$ (c $\left.0.005, \mathrm{CHCl}_{3}\right) .{ }^{1} \mathrm{H}-\mathrm{NMR}\left(\mathrm{CDCl}_{3}\right): \delta 0.98(\mathrm{t}, J=6.7 \mathrm{~Hz}, 3 \mathrm{H}, \mathrm{H}-15), 1.23(\mathrm{~d}, J=6.5 \mathrm{~Hz}, 3 \mathrm{H}$, H-16), 1.43 (m, 1H, H-14a), 1.52 (s, 3H, H-19), 1.52 (s, 3H, H-20), 1.78 (m, 1H, H-14b), 1.86 $(\mathrm{dq}, J=6.9$ and $0.8 \mathrm{~Hz}, 3 \mathrm{H}, \mathrm{H}-21), 1.97$ (bs, 3H, H-22), 3.73 (s, $\left.J=6.5 \mathrm{~Hz}, 3 \mathrm{H}, \mathrm{OCH}_{3}\right), 3.83$ (sext, $J=6.5 \mathrm{~Hz}, 1 \mathrm{H}, \mathrm{H}-13), 5.66$ (d, $J=10.0 \mathrm{~Hz}, 1 \mathrm{H}, \mathrm{H}-7), 6.11$ (s, 1H, H-3), 6.49 (qq, $J=6.9$ and $1.1 \mathrm{~Hz}, 1 \mathrm{H}, \mathrm{H}-10), 6.55(\mathrm{~d}, J=10.0 \mathrm{~Hz}, 1 \mathrm{H}, \mathrm{H}-8)$. Spectroscopic data (Figure S10) were in good agreement with the literature [18].

Tamanolide D. UV (n-hexane/AcOEt, 78/22, v/v): $\lambda_{\max }(\mathrm{nm}) 296,248 .[\alpha]^{\mathrm{D}}{ }_{25}=-40.5^{\circ}$ (c $\left.0.006, \mathrm{CHCl}_{3}\right) .{ }^{1} \mathrm{H}-\mathrm{NMR}\left(\mathrm{CDCl}_{3}\right): \delta 0.78(\mathrm{~d}, J=7.2 \mathrm{~Hz}, 3 \mathrm{H}, \mathrm{H}-22), 0.95(\mathrm{t}, J=7.3 \mathrm{~Hz}, 3 \mathrm{H}$, H-15), 1.20 (d, J = 6.9 Hz, 3H, H-16), 1.41 (d, J = 6.5 Hz, 3H, H-21), 1.44 (m, 1H, H-14a), 1.46 (s, 3H, H-20), 1.47 (s, 3H, H-19), 1.76 (m, 1H, H-14b), 2.01 (qt, J = 7.2 and $2.0 \mathrm{~Hz}, 1 \mathrm{H}, \mathrm{H}-11$ ), 3.84 (sext, $J=6.6 \mathrm{~Hz}, 1 \mathrm{H}, \mathrm{H}-13), 4.49$ (qd, $J=6.5$ and $2.0 \mathrm{~Hz}, 1 \mathrm{H}, \mathrm{H}-10), 4.83$ (d, $J=2.0 \mathrm{~Hz}$, $1 \mathrm{H}, \mathrm{H}-12), 5.52$ (d, J = 10.0 Hz, 1H, H-7), 6.06 (s, 1H, H-3); 6.64 (d, J = $10.0 \mathrm{~Hz}, 1 \mathrm{H}, \mathrm{H}-8$ ). Spectroscopic data (Figures S11 and S17) were in good agreement with the literature [18].

Tamanolide P. ${ }^{1} \mathrm{H}-\mathrm{NMR}\left(\mathrm{CDCl}_{3}\right): \delta 0.99(\mathrm{t}, J=7.0 \mathrm{~Hz}, 3 \mathrm{H}, \mathrm{H}-15), 1.18(\mathrm{~d}, J=7.0 \mathrm{~Hz}, 3 \mathrm{H}$, H-22), 1.23 (d, J = 6.7 Hz, 3H, H-16), 1.45 (d, $J=6.3 \mathrm{~Hz}, 3 \mathrm{H}, \mathrm{H}-21), 1.45$ (m, 1H, H-14a), 1.50 (s, 3H, H-20), 1.50 (s, 3H, H-19), 1.79 (m, 1H, H-14b), 1.79 (dqd, J = 10.8, 7.0 and 3.2 Hz, $1 \mathrm{H}, \mathrm{H}-11$ ), 3.88 (sext, $J=6.7 \mathrm{~Hz}, 1 \mathrm{H}, \mathrm{H}-13), 4.29$ (qd, $J=10.8$ and $6.3 \mathrm{~Hz}, 1 \mathrm{H}, \mathrm{H}-10), 4.99$ (d, $J=3.2 \mathrm{~Hz}, 1 \mathrm{H}, \mathrm{H}-12), 5.55$ (d, J = 10.0 Hz, 1H, H-7), 6.08 (s, 1H, H-3), 6.66 (d, J = $10.0 \mathrm{~Hz}$, $1 \mathrm{H}, \mathrm{H}-8)$. Spectroscopic data (Figure S13) were in good agreement with the literature [18].

\subsection{Antioxidant Assays}

\subsubsection{Chemicals, Enzymes and Instrumentation}

The standards 6-hydroxy-2,5,7,8-tetramethylchroman-2-carboxylic acid (Trolox) and 2,2'-azobis(2-amidinopropane) dihydrochloride (AAPH) were from Acros Organics. Glycine buffer, Tris- $\mathrm{HCl}$ buffer, xanthine, xanthine oxidase (XO; from buttermilk), proteinase $\mathrm{K}$ (PTA), bovine serum albumin (BSA), diclofenac sodium salt, 1,1'-diphenyl-2-picrylhydrazyl (DPPH), lucigenin ( $N, N$-dimethyl-9,9-biacridinium dinitrate), 2-thiobarbituric acid (TBA), allopurinol, luminol (5-amino-2,3-dihydro-phthalazine-1,4-dione), tert-butylhydroperoxide $(t \mathrm{BuOOH})$, superoxide dismutase (SOD), catalase (CAT) and all other reagents were from Sigma-Aldrich. Phosphate-buffered saline (PBS) was from Life Technology Corp. (St Aubin, France).

DPPH decay and enzyme inhibition assays were performed on microplates. Luminescence was measured at room temperature on a Sirius luminometer (Titertek Berthold, Pforzheim, Germany) operating at 300-600 nm. 


\subsubsection{Xanthine-Oxidase Inhibition}

All reactants were dissolved in PBS (0.2 M, pH 7.5). The experiments were performed at $37^{\circ} \mathrm{C}$ in 96-wells microplates with a final volume of $250 \mu \mathrm{L} /$ well [30]. Wells were filled with $150 \mu \mathrm{L}$ of either the test extracts $(15-260 \mu \mathrm{g} / \mathrm{mL})$, allopurinol $(0.25-5 \mu \mathrm{M})$ or PBS (blank controls). To all wells, $25 \mu \mathrm{L}$ of EDTA ( $0.1 \mathrm{mM}$ in PBS) and $25 \mu \mathrm{L}$ of xanthine solution $(500 \mu \mathrm{M})$ were then added, and the reaction was started by adding $50 \mu \mathrm{L}$ of $\mathrm{XO}$ suspension $(23.32 \mathrm{mU} / \mathrm{mL})$, while PBS $(50 \mu \mathrm{L})$ was added in blank samples. The final concentrations were: xanthine, $50 \mu \mathrm{M}$; EDTA, $10 \mu \mathrm{M}$ and XO, $4.7 \mathrm{mU} / \mathrm{mL}$. The wells were incubated for $30 \mathrm{~min}$ at $37^{\circ} \mathrm{C}$, and uric acid production was determined by subtracting the absorbance at $290-295 \mathrm{~nm}$ of the sample against that of the blank. Each measurement was performed in triplicate.

\subsubsection{Superoxide Radical Quenching}

Superoxide $\left(\mathrm{O}_{2}{ }^{--}\right)$inhibition was evaluated in glycine buffer $(6.25 \mathrm{mM}, \mathrm{pH} 10.1)$ /acetone medium using an allopurinol- $\mathrm{XO}$ generating system coupled with lucigenin assay. All reactants were dissolved in glycine buffer, and the reaction was carried out at $25^{\circ} \mathrm{C}$ [30]. Briefly, to glycine buffer $(1.275 \mathrm{~mL})$ were sequentially added $0.425 \mathrm{~mL}$ of acetone, $300 \mu \mathrm{L}$ of allopurinol solution $(100 \mu \mathrm{M}$; final concentration $17.6 \mu \mathrm{M}), 3-25 \mu \mathrm{L}$ of test compound solution $(20 \mathrm{mg} / \mathrm{mL}$ in DMSO) and $300 \mu \mathrm{L}$ of lucigenin solution $(100 \mu \mathrm{M}$; final concentration $17.6 \mu \mathrm{M})$. The test tube was inserted in the luminometer, and reaction was initiated by adding a XO suspension $(2 \mu \mathrm{L}, 11 \mathrm{mU} / \mathrm{mL})$. Luminescence was monitored for a total period of $7 \mathrm{~min}$ and $\mathrm{O}_{2}{ }^{--}$quenching was calculated by subtracting areas under the curve against blank. Each measurement was performed in triplicate.

\subsubsection{Metal Chelating Capacity (MCC)}

The MCC of each extract was measured according to a protocol adapted for microplates [23]. Samples $(200 \mu \mathrm{L} /$ well $)$ dissolved in methanol at $0.3-2.4 \mathrm{mg} / \mathrm{mL}$ were mixed with $10 \mu \mathrm{L}$ of aqueous ferrous chloride $(2 \mathrm{mM})$. The mixture was then reacted with $40 \mu \mathrm{L} /$ well of $5 \mathrm{mM}$ aqueous 3-(2-pyridyl)-5,6-bis(4-phenylsulfonic acid)-1,2,4-triazine (ferrozine; Sigma-Aldrich, Saint-Quentin Fallavier, France) for $10 \mathrm{~min}$ at room temperature under vigorous stirring. The absorbance was read at $562 \mathrm{~nm}$, and a calibration curve was constructed using EDTA as a standard. Percent inhibition of $\left[\mathrm{Fe}^{2+}-\right.$ ferrozine] complex was calculated against control well absorbance (water instead of extract). The results are expressed as micromoles of EDTA equivalents (EDTAE) per gram of extract weight.

\subsubsection{Assay of Proteinase and Lipoxygenase Inhibitory Activities}

Anti-inflammatory properties of the extracts were evaluated by their proteinase and lipoxygenase inhibitory activities as described [31]. Briefly, PTA (0.06 mg) was dissolved in $2 \mathrm{~mL}$ of Tris $\mathrm{HCl}$ buffer $(20 \mathrm{mM}, \mathrm{pH} 7.4)$ containing a suspension of each extract $(100-600 \mu \mathrm{g} / \mathrm{mL})$. The mixture was incubated at $37^{\circ} \mathrm{C}$ for $5 \mathrm{~min}$, and $1 \mathrm{~mL}$ of $4 \%$ BSA was added. Incubation was prolonged for $20 \mathrm{~min}$, and afterwards $2 \mathrm{~mL}$ of $5 \%$ trichloroacetic acid was added to the mixture. After centrifugation $\left(3000 \mathrm{rpm}, 10 \mathrm{~min}, 4^{\circ} \mathrm{C}\right)$ the absorbance was read at $210 \mathrm{~nm}$ against buffer as blank, and the percentage of proteinase inhibition activity was calculated. Experiments were performed in triplicate and averaged. The antiinflammatory drug diclofenac $(100-300 \mu \mathrm{g} / \mathrm{mL})$ was used as a standard for comparison.

Lipoxygenase (15-LOX, soybean) inhibitory activity was evaluated using a commercial assay kit (Cayman Chemicals Co; Item No. 760700) according to the manufacturer's instructions. Solutions of test samples $(10 \mu \mathrm{L})$ in methanol were added into 96-wells plates together with assay buffer, and the enzyme was added. The reaction was initiated by adding $10 \mu \mathrm{L}$ of arachidonic acid to the wells and the plate was placed on a shaker for $15 \mathrm{~min}$. Chromogen solution $(100 \mu \mathrm{L})$ was added to the wells, the plate was then placed on a shaker for $10 \mathrm{~min}$ and absorbance was read at $495-500 \mathrm{~nm}$. The flavonoid quercetin $(50-100 \mu \mathrm{M})$ was used as a standard. Results are expressed as a percentage relative to the activity without the test compound. 


\subsubsection{DPPH Assay}

Experiments were performed according to previous procedures [22,23]. Aliquots of dichloromethane solutions of oil or fractions $(50-500 \mathrm{mg} / \mathrm{mL}$ ) or test compounds (final concentration $0.01-2 \mathrm{mM}$ ) were added to $200 \mu \mathrm{L}$ of a freshly prepared DPPH solution $(75 \mathrm{mg} / \mathrm{L})$, and the final volume was adjusted to $300 \mu \mathrm{L}$ with dichloromethane to obtain a final DPPH concentration of $0.13 \mathrm{mM}$. The absorbance was read at $517 \mathrm{~nm}$ on a microplate reader $3 \mathrm{~min}$ after sample addition. Experiments were performed in triplicate and averaged. The DPPH inhibition was calculated as follows:

$$
\text { Inhibition }(\%)=\left[100 \times\left(\mathrm{A}_{0}-\mathrm{A}\right) / \mathrm{A}_{0}\right]
$$

For each compound, concentration resulting in 50\% DPPH scavenging ( $\mathrm{IC}_{50}$ value) was calculated using Prism 6 software (GraphPad, San Diego, CA, USA).

\subsubsection{Total Peroxyl Radical-Trapping Potential (TRAP) Assay}

The experimental protocol of the TRAP assay was previously reported [30]. Briefly, AAPH $(150 \mathrm{mM})$ was dissolved in $10 \mathrm{~mL}$ of Tris $\mathrm{HCl}$ buffer solution (100 mM, pH 7.4), and the solution was kept at $37^{\circ} \mathrm{C}$ for $30 \mathrm{~min}$ to initiate thermal radical formation. A luminol stock solution $(1 \mathrm{mM})$ was prepared in $50 \mathrm{~mL}$ Tris $\mathrm{HCl}$ buffer and kept in darkness at $4{ }^{\circ} \mathrm{C}$. A $78 \mu \mathrm{M}$, working luminol solution was prepared before each assay by dilution in Tris $\mathrm{HCl}$ buffer. Samples for assays were prepared as follows: $2 \mathrm{~mL}$ of AAPH (final concentration, $100 \mathrm{mM}$ ) and $500 \mu \mathrm{L}$ of luminol solution (final concentration, $13 \mu \mathrm{M}$ ) were introduced in a $3 \mathrm{~mL}$ tube; then, $500 \mu \mathrm{L}$ of pure acetone (blank) or solution of the tested oil or extract in acetone $(0.005-0.2 \mathrm{mg} / \mathrm{mL}$ ) or DMSO (test compounds: $5-300 \mu \mathrm{M}$ ) were added and the mixture vortexed for $5 \mathrm{~s}$ before luminescence analysis. A calibration curve was obtained in the same conditions using the antioxidant Trolox $(1-40 \mu \mathrm{M})$ as a standard.

Quantification of radical scavenging capacity was performed by integrating the area under the curve (AUC) for the sample and blank solutions, and the results are expressed as Trolox Equivalents (TE) using Equation (2):

$$
\mathrm{TE}=\left([\text { Trolox }] \times \Delta \mathrm{AUC}_{\text {Sample }}\right) /\left([\text { Sample }] \times \Delta \mathrm{AUC}_{\text {Trolox }}\right)
$$

where $\triangle \mathrm{AUC}$ Sample (Trolox) $=$ AUC Blank - AUC Sample (Trolox).

\subsection{Biological Experiments}

\subsubsection{Cell Culture and Reagents}

Doubly distilled deionized water was used throughout, and solutions were passed through a $0.2 \mu \mathrm{m}$ Millipore filter before use. Culture media Dulbecco's modified Eagle medium (DMEM), Roswell Park Memorial Institute medium (RPMI), Eagle's minimal essential medium (MEM), GlutaMax ${ }^{\circledR}$ and fetal calf serum (FCS) were from Life Technologies. Other reactants such as 1,1,3,3-tetramethoxypropane (TMP), 3-(4,5-dimethylthiazol-2-yl)2,5-diphenyltetrazolium bromide (tetrazolium dye, MTT) and Triton X-100 were from Acros Organics or Sigma-Aldrich.

The microorganisms M. tuberculosis H37 RV (ATCC 27294, France) and Staphylococcus aureus (ATCC 6538, France) strains were a gift from IRD-Aix Marseille University and were cultured according to [12] and [32], respectively. Murine 3T3 fibroblasts (ATCC-LGC Promochem, Molsheim, France) were maintained in the culture at $37{ }^{\circ} \mathrm{C}$ in a $5 \% \mathrm{CO}_{2}$ humidified atmosphere in DMEM containing $1 \%$ glucose and supplemented with $10 \%$ FCS, $100 \mathrm{U} / \mathrm{mL}$ penicillin and $100 \mathrm{mg} / \mathrm{mL}$ streptomycin essentially as described earlier [33]. Cells were plated in 24-well dishes, and the medium was replenished every 2 days until confluency, which was checked by microscopic observation. A549 human lung carcinoma cells were cultured at $37^{\circ} \mathrm{C}$ in an atmosphere of $5 \% \mathrm{CO}_{2}$ in RPMI supplemented with $10 \%$ FCS, $100 \mathrm{U} / \mathrm{mL}$ penicillin, $100 \mu \mathrm{g} / \mathrm{mL}$ streptomycin and $2 \mathrm{mM}$ GlutaMax ${ }^{\circledR}$ [23]. Flasks containing confluent cells were trypsinized, and cells were seeded in 96-well plates at 
a density of $2 \times 10^{4}$ cells per well in complete RPMI and incubated for $48-72 \mathrm{~h}$ with test compounds.

\subsubsection{Antimicrobial and Anti-Mycobacterial Activity}

The antimicrobial activity was evaluated against the microorganism S. aureus (ATCC 6538, France) according to the disk-diffusion agar method [34]. Briefly, $20 \mu \mathrm{L}$ per aliquots of each compound (stock solutions of $1 \mathrm{mg} / \mathrm{mL}$ in DMSO) were impregnated on a paper disc. After $24 \mathrm{~h}$ incubation at $37^{\circ} \mathrm{C}$, the diameter of the zone of inhibition was determined. The antibiotic oxacillin ( $20 \mu \mathrm{L}$ of a $1 \mathrm{mg} / \mathrm{mL}$ solution in DMSO) was used as the positive control.

The anti-mycobacterial activity was assessed against $M$. tuberculosis $\mathrm{H} 37 \mathrm{RV}$ using the colorimetric Microplate-based Alamar Blue assay (MABA) [12]. For each test compound, the minimum inhibitory concentration (MIC), which is the lowest concentration inhibiting the visible growth of the microorganism after $24 \mathrm{~h}$ incubation at $37^{\circ} \mathrm{C}$, was expressed in $\mu \mathrm{g} / \mathrm{mL}$ from at least 3 independent experiments. The antibiotic streptomycin was studied for comparison.

\subsubsection{Cytotoxicity Assays}

The cytotoxicity of TO, resin fractions and test compounds were evaluated on 3T3 fibroblasts and A549 cells using the MTT assay performed in microplates [30,33]. Briefly, following $48 \mathrm{~h}$ incubation at $37^{\circ} \mathrm{C}$ with TO or fractions $(0.001-1000 \mu \mathrm{g} / \mathrm{mL})$, MTT in PBS $1 \mathrm{X}(+/+)(5 \mathrm{mg} / \mathrm{mL})$ was added to the medium (final concentration, $0.5 \mathrm{mg} / \mathrm{mL})$ and incubation was extended for $4 \mathrm{~h}$ at $37^{\circ} \mathrm{C}$. Then, medium was removed and DMSO $(100 \mu \mathrm{L})$ was added to each well and incubated for $15 \mathrm{~min}$ with agitation in a shaking incubator. The conversion of MTT to a purple formazan precipitate was monitored at $570 \mathrm{~nm}$. The inhibition of cell viability $\left(\mathrm{IC}_{50}\right)$ was calculated using linear regression calculations from at least 5 different concentrations for each sample.

\subsubsection{Experiments on $3 \mathrm{~T} 3$ Cells Exposed to $\mathrm{tBuOOH}$}

Aliquots of test compounds $(10-20 \mu \mathrm{L})$ diluted in phenol-red-free DMEM medium containing $1 \%$ glucose were transferred into the culture wells pre-filled with the appropriate volume of medium to reach a final volume of $0.5 \mathrm{~mL} /$ well. After $2 \mathrm{~h}$ incubation, oxidative stress was induced by incubating the cells with $t \mathrm{BuOOH}(0.40 \mathrm{mM})$ for $4 \mathrm{~h}$ [35]. Then, the supernatants were sampled for cytoplasmic LDH release, and the adherent cells were preincubated for $2 \mathrm{~h}$ in MEM containing neutral red $(50 \mu \mathrm{g} / \mathrm{mL})$ and $2 \%$ FCS. Cell viability was determined in a microplate reader by monitoring the absorption difference between 560 and $620 \mathrm{~nm}$. In the second set of wells, both LDH release and cellular MDA-TBA contents were assayed in supernatants and scraped cells, respectively. LDH activity was assessed at $340 \mathrm{~nm}$ using a commercial detection kit (Biolabo, Maizy, France). Protein measurement was performed in 4 out of 24 randomly selected wells. To determine the total LDH content (i.e., the sum of the enzymatic activity in the lysate and the culture medium), 1\% Triton X-100 was added to randomly selected wells of untreated cells. Then, the cells were scraped and homogenized in serine-borate buffer and the MDA content of the suspension was measured by HPLC using UV-visible detection according to a previously reported procedure [22]. Results were compared to control cells treated with DMEM + $0.1 \%$ DMSO. Data represent 6 independent experiments made in duplicate for each test compound and resin concentration and are expressed in arbitrary units $/ \mathrm{mg}$ of protein.

\subsubsection{Experiments on UV Irradiated Rat Skin Slices}

Skin samples were obtained from the back of six normal Sprague Dawley rats (CERJ, Le Genest St Isle, France) weighing 100-150 $\mathrm{g}$ within $2 \mathrm{~h}$ after sacrifice by intraperitoneal injection of pentobarbital (120 mg/kg; Ceva Santé Animale, Libourne, France). Before sacrifice, animals were used for other experiments than the present study (agreement for animal experimentation APAFiS 2015102022108840). Animal care was performed according to the rules of the European Union Council (Revised Directives 2010/63/EU). Aix 
Marseille University and the CNRS have a license for animal housing and experimentation (agreement C13-055-06), and the study was under the supervision of a vet at the CNRS.

Skin samples were shaved, rinsed first in water and then three times in $125 \mathrm{mM}$ aqueous $\mathrm{KCl}$, dried, cut into slices of about $15 \times 10 \times 0.5 \mathrm{~mm}$ size and kept for $1 \mathrm{~h}$ on agar plates at $4{ }^{\circ} \mathrm{C}$ [21]. Afterwards, skin samples were placed at the surface of a filter paper soaked with aqueous $\mathrm{KCl}$ to avoid any dehydration and maintained for $10 \mathrm{~min}$ at $37^{\circ} \mathrm{C}$. Each test extract $(50 \mu \mathrm{g})$ was emulsified with $100 \mu \mathrm{L}$ of olive oil and spread on the surface of the skin slice [16]. They were allowed to stabilize for $1 \mathrm{~h}$ at $37^{\circ} \mathrm{C}$ before exposure for $1 \mathrm{~h}$ to a UVA/UVB solar simulator ( 150 W, 280-400 nm; Lot-Oriel, Palaiseau, France) in the conditions of a phototoxic dose [22]. Following irradiation, the slices were separated into two groups.

In the first group, the slices were first homogenized in 5 volumes of aqueous $\mathrm{KCl}$ $(125 \mathrm{mM})$. Afterwards, homogenates $(0.25 \mathrm{~mL})$ were added $0.7 \mathrm{~mL}$ of $5 \%$ trichloroacetic acid and $50 \mu \mathrm{L}$ of $0.2 \%$ butylated hydroxytoluene, the mixture was incubated for $60 \mathrm{~min}$ at $95{ }^{\circ} \mathrm{C}$, quickly cooled to room temperature and centrifugated $\left(1000 \times g\right.$ at $\left.4{ }^{\circ} \mathrm{C}\right)$, and the supernatant was mixed with an equal volume of saturated aqueous TBA solution and re-incubated for $60 \mathrm{~min}$ at $95^{\circ} \mathrm{C}$. After cooling, each sample was extracted with $2 \mathrm{~mL}$ of butanol/pyridine, 15/1, $(v / v)$ and the absorbance of the MDA-TBA complex was read at $532 \mathrm{~nm}$. A calibration curve was obtained from standard MDA-TBA samples prepared by using $0.25 \mathrm{~mL}$ of $0.1-15 \mathrm{mmol} / \mathrm{L}$ of TMP solutions instead of skin homogenate. Data are representative of 6 independent experiments for each sample and are expressed as $\mu \mathrm{mol} / \mathrm{mg}$ protein.

In the second group, each skin slice was covered with $0.5 \mathrm{~mL}$ of PBS before receiving one $20-\mu \mathrm{L}$ aliquot of the nitrone 5-(diethoxyphosphoryl)-5-methyl-1-pyrroline $\mathrm{N}$-oxide (DEPMPO) [36] (final concentration, $15 \mathrm{mM}$ ) in PBS immediately after irradiation was switched off. Slices were incubated in the dark for $15 \mathrm{~min}$ at room temperature to allow for spin adduct build-up. Afterwards, the supernatants were transferred into cryotubes and immediately stored in liquid $\mathrm{N}_{2}$ for delayed electron paramagnetic resonance (EPR) analysis.

\subsubsection{EPR Experiments}

Samples for EPR were sequentially thawed, placed into calibrated $50 \mu \mathrm{L}$ glass capillaries and single scanned for their spin adduct content using a Bruker ESP 300 spectrometer (Karlsruhe, Germany) operating at X-band $(9.81 \mathrm{GHz})$ with a $100-\mathrm{KHz}$ modulation frequency. Spectra (magnetic field resolution, 2048 points) were recorded at room temperature $1 \mathrm{~min}$ after thawing of the sample using the following parameters: microwave power, $10 \mathrm{~mW}$; modulation amplitude, $0.63 \mathrm{G}$; receiver gain, $5 \times 10^{5}$; time constant, $20.48 \mathrm{~ms}$; and scan rate, $0.7 \mathrm{G} / \mathrm{s}$ for a sweep width of $120 \mathrm{G}$. Computer simulations of the EPR signals were carried out assuming they consisted of varying mixtures of DEPMPO-OH, the DEPMPO/hydroxyl radical (HO•) spin adduct (giving an 8-line spectrum with coupling constants $\mathrm{a}_{\mathrm{N}}=14.0 \mathrm{G} ; \mathrm{a}_{\mathrm{H}}=13.3 \mathrm{G}$ and $\mathrm{a}_{\mathrm{P}}=47.2 \mathrm{G}$ ) and DEPMPO$\mathrm{OOH}$ (the DEPMPO/O $\mathrm{O}_{2}{ }^{\bullet-}$ spin adduct), the main trans-DEPMPO-OOH diastereoisomer of which existing as two fast-exchanging rotamers $(65: 35 \%)$, both giving 12-lines spectra with $\mathrm{a}_{\mathrm{N}}=13.3(12.9) \mathrm{G} ; \mathrm{a}_{\mathrm{H}}=12.2(8.6) \mathrm{G}$ and $\mathrm{a}_{\mathrm{P}}=53.9(43.0) \mathrm{G}[22,36]$ (see structures in Scheme S1). Relative spin adduct concentrations were obtained by double integration of the simulated signals using WinSim software [37].

\subsubsection{Statistical Analysis}

All values are expressed as mean \pm SD or SEM for the indicated number of independent experiments. Differences were analyzed by one- or two-way analysis of variance (ANOVA) followed by appropriate a posteriori tests. Intergroup differences were considered significant at $p<0.05$. 


\section{Results and Discussion}

\subsection{Chemistry, HPLC, TPC and TFC Analyses}

Tamanu oil was obtained from crushed air-dried mature seeds of $C$. inophyllum as a green oil with a heavy texture. As a rather high acid index value (14-40) was found for the oil (data not shown), the presence of amounts of organic acids was expected. After filtration, fractionations were performed to give the methanol (MeTO) and ethanol (EtTO) soluble extracts (Scheme 1). Ethanol was preferred to other solvents (e.g., $n$-hexane or ethyl acetate) for more efficiently removing fatty acids, triglycerides and tannins [4], whereas methanol is highly efficient for recovering amounts of polar phenolics and flavonoids [20,23]. Then, EtTO was further separated according to a multistep procedure into neutral (NTR) and acidic (ATR) fractions, while MeTO resin was kept unchanged for further analysis. A methanolic extract of EtTO was prepared to yield the MeETR fraction.

LPLC on NTR and ATR resins led to ten and four subfractions, respectively. Fractions of middle polarity containing substances with keto or hydroxyl groups, as indicated by TLC analysis (see Methods), were then submitted to further HPLC separation. In our hands, fifteen pyranocoumarin derivatives were identified, fourteen from the NTR fraction: inophyllums (C, D, E, P), calophyllolide, calanolides (A, B, D, GUT 70, epicalanolide C, 12-oxacalanolide A) and three tamanolides (tamanolide, tamanolides D and P), and one from the ATR fraction, i.e., inocalophyllin B (Figure 1). The structure of each phytoconstituent was assigned according to its ${ }^{1} \mathrm{H}-\mathrm{NMR}$ spectrum, MS analysis and ${ }^{13} \mathrm{C}-$ NMR for some products (see Supplementary Information) and compared to literature data if the same metabolites were obtained previously from other natural sources or by chemical synthesis. For derivatives obtained with at least $97 \%$ purity (by HPLC), optical activities were measured (see Materials and Methods).

Inophyllums C, D, E and P have been previously reported in C. inophyllum leaves or limbs from Malaysia [10,38]. Inophyllum C was also found in C. inophyllum nuts from Madagascar and leaves of C. inophyllum from French Polynesia [39]. Inophyllum E was isolated in the C. inophyllum oil from Fiji Islands [7]. However, the present work is the first detailed report of inophyllums D and P isolated from C. inophyllum oil and the first report of inophyllums $\mathrm{C}$ and $\mathrm{E}$ in the oil from French Polynesian species.

Moreover, three other calanolides were isolated as pure compounds from EtTO extract, i.e., calanolides A and D, and 12-oxocalanolide. Of these three compounds, only calanolide A has been already isolated in Calophyllum lanigerum [6] and Calophyllum brasiliense [40]. In C. inophyllum, only calanolide GUT 70 has been previously reported from Madagascar species [41], being later isolated from the stem bark of C. brasiliense [42]. However, to the best of the authors' knowledge, this is the first time that calanolide GUT 70 has been ever identified in C. inophyllum from French Polynesia, based on NMR $\left({ }^{1} \mathrm{H}\right.$ and $\left.{ }^{13} \mathrm{C}\right)$ and UV data (see Section 2.1.6 and Supplementary Information), in good agreement with those reported from other natural species $([6,40]$ or from chemical synthesis [43]. Furthermore, this study also reports on the first identification of calanolide $\mathrm{D}$ and 12-oxocalanolide $\mathrm{A}$ from a natural source, both compounds being previously obtained by chemical synthesis [26,29]. Calanolide D was claimed to have been isolated from C. lanigerum [6], but the structure of the molecule was reassigned later as being a regioisomer, pseudo-calanolide $\mathrm{D}$, in which the pyran ring positions are inverse with respect to the coumarin moiety [9,26,29]. Moreover, the synthesis of both pseudo-calanolides D and calanolide D in their racemic forms was reported, and the authors highlighted small differences in their ${ }^{1} \mathrm{H}-\mathrm{NMR}$ spectra, mainly affecting the C-8 pyran ring protons [26]. In the present work, according to ${ }^{1} \mathrm{H}-\mathrm{NMR}$ spectra (see Supplementary Information), the molecule isolated from C. inophyllum corresponds to the calanolide D structure as shown in Figure 1. Indeed, the ${ }^{1} \mathrm{H}-\mathrm{NMR}$ doublet at $6.65 \mathrm{ppm}$ was unambiguously attributed to the $H-\mathrm{C}-8$ belonging to the pyran ring. Unfortunately, the relatively low purity of the sample ( $96 \%$ by HPLC) could not allow the determination of the dextro- or levogyre nature of the enantiomer. 


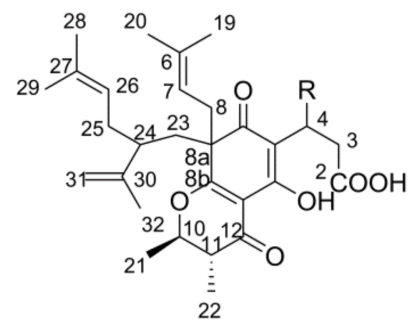

Inocalophyllin $\mathbf{B}: \mathrm{R}=n-\mathrm{Pr}$ Inocalophyllin $\mathrm{A}: \mathrm{R}=\mathrm{Ph}$

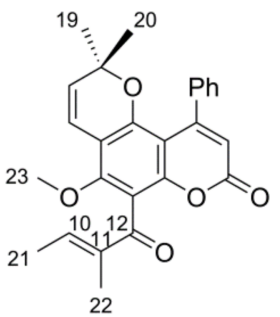

Calophyllolide

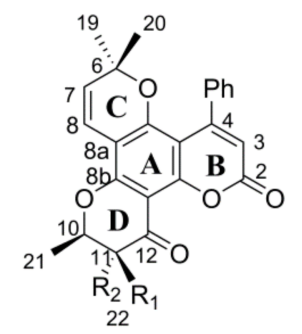

Inophyllum $\mathrm{C}: \mathrm{R}_{1}=\mathrm{H}, \mathrm{R}_{2}=\mathrm{Me}$ Inophyllum $E: R_{1}=M e, R_{2}=H$<smiles>[R17]C1C(=O)Oc2c3c(c4ccc(=O)oc4c2C=CC(C)(C)O3)OC1C</smiles>

Inophyllum $\mathbf{P}: \mathrm{R}_{1}=\mathrm{H}, \mathrm{R}_{2}=\mathrm{Me}$ Inophyllum $D: R_{1}=M e, R_{2}=H$

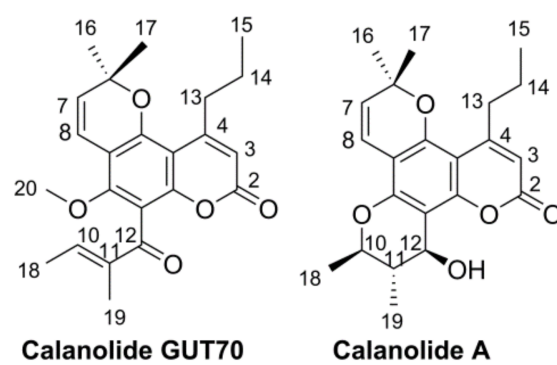

Calanolide GUT70
Calanolide A<smiles>[R1]C1Oc2c(O)c(c3c(c2CCCC)OC(C)(C)C=C3)OC1C</smiles>

Calanolide B: $\mathrm{R}_{1}=\mathrm{H}, \mathrm{R}_{2}=\mathrm{Me}$ Epi-calanolide C: $\mathrm{R}_{1}=\mathrm{Me}, \mathrm{R}_{2}=\mathrm{H}$<smiles>[R1]C1([R1])C(=O)c2c(c3c(c4c(CCC)cc(=O)oc24)OC(C)(C)C=C3)O[C@H]1C</smiles>

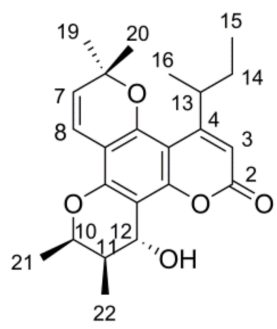

(-)-Tamanolide D

12-oxocalanolide $\mathbf{A}: \mathrm{R}_{1}=\mathrm{H}, \mathrm{R}_{2}=\mathrm{Me}$ Calanolide $\mathrm{D}: \mathrm{R}_{1}=\mathrm{Me}, \mathrm{R}_{2}=\mathrm{H}$

Figure 1. Structure of the secondary metabolites belonging to the pyranocoumarin family isolated from NTR and ATR fractions by low-pressure column chromatography and HPLC separation. ${ }^{1} \mathrm{H}$ NMR, ${ }^{13} \mathrm{C}-\mathrm{NMR}$ and MS spectra are reported in Supplementary Information.

The spectroscopic parameters of the compound assigned to 12-oxocalanolide A were in good agreement with those obtained by organic synthesis [26,44]. Of interest, two other calanolides were observed as minor constituents, i.e., calanolide B in Fraction P (which contained also inophyllum $\mathrm{P}$ and tamanolide $\mathrm{P}$ ) and the epi-calanolide $\mathrm{C}$ in mixture with tamanolide D and inophyllum D in Fraction D. Again, the ${ }^{1} \mathrm{H}-\mathrm{NMR}$ data were in good agreement with the literature $[6,26,45]$.

According to their HPLC purity and availability requirements, ten isolated C. inophyllum oil metabolites and the fully characterized multi-components Fraction P were selected for further antioxidant and biological evaluations, together with the DTO, MeTO, MeETR, EtTO, NTR and ATR extracts. First, it was considered interesting to quantitate the TPC and TFC values in crude oil and extracts. The data reported in Table 1 show that using ethanol as starting material for fractionation significantly favored the recovery of phenolic compounds, i.e., a 3-6 fold increase in TPC values was found in EtTO, ATR and especially NTR extracts, and a 2-7 fold increase in TFC values was found in EtTO, NTR and especially ATR extracts, as compared to the crude oil. Regarding TPC and TFC values methanol was globally a less efficient extraction solvent in both $\mathrm{MeOH}$ and MeETR extracts (Table 1). No measurable amounts of phenolic and flavonoid derivatives were found in the de-resinated DTO fraction. 
Table 1. Total phenolic (TPC) and total flavonoid (TFC) contents, xanthine oxidase $(\mathrm{XO})$ inhibition, superoxide $\left(\mathrm{O}_{2}{ }^{\bullet-}\right)$ quenching, metal chelating capacity (MCC), proteinase (PTA) and lipoxygenase (15-LOX) inhibitory activities of Tamanu oil (TO), its de-resinated lipid fraction (DTO), methanolic (MeTO and MeETR) and ethanolic (EtTO) extracts and neutral (NTR) and acidic (ATR) subfractions of EtTO.

\begin{tabular}{|c|c|c|c|c|c|c|c|}
\hline \multirow[t]{2}{*}{ Compound } & $\mathrm{TPC}^{\mathrm{a}}$ & TFC $^{b}$ & XO Inhibition & $\begin{array}{c}\mathrm{O}_{2}^{\bullet-} \\
\text { Quenching }\end{array}$ & MCC & $\begin{array}{c}\text { PTA } \\
\text { Inhibition } \\
d\end{array}$ & $\begin{array}{c}\text { 15-LOX } \\
\text { Inhibition }\end{array}$ \\
\hline & (mg GAE/g) & (mg RUE/g) & $\mathrm{IC}_{50}{ }^{\mathrm{c}}(\mu \mathrm{g} / \mathrm{mL})$ & $\mathrm{IC}_{50}(\mu \mathrm{g} / \mathrm{mL})$ & ( $\mu \mathrm{mol}$ EDTAE/g) & $(\%)$ & $(\%)$ \\
\hline & \multicolumn{7}{|c|}{ Oils and fractions } \\
\hline Tamanu oil (TO) & $14 \pm 2$ & $3.8 \pm 0.5$ & $951 \pm 6$ & $565 \pm 6$ & $21 \pm 1$ & $10 \pm 1$ & $12 \pm 1$ \\
\hline Sesame oil & $12 \pm 1$ & $1.5 \pm 0.4$ & $831 \pm 4$ & $469 \pm 5$ & $20 \pm 2$ & $12 \pm 1$ & $13 \pm 3$ \\
\hline DTO & $\sim 0$ & $\sim 0$ & $>1000$ & $>1000$ & $\sim 0$ & $\sim 0$ & $\sim 0$ \\
\hline МeTO & $44 \pm 3^{*}$ & $15.4 \pm 0.7^{* \#}$ & $152 \pm 2$ *\# & $22.1 \pm 0.5$ *\# & $31 \pm 3.1 * \#$ & $31 \pm 2$ *\# & $25 \pm 2$ *\# \\
\hline EtTO & $51 \pm 2 *$ & $19.4 \pm 0.2 *$ & $102 \pm 1 *$ & $18.0 \pm 0.1 *$ & $45 \pm 2 *$ & $62 \pm 4^{*}$ & $31 \pm 2 *$ \\
\hline MeETR & $35 \pm 2 *$ & $10.9 \pm 0.8 *$ & $152 \pm 2$ *\# & $25.1 \pm 0.5^{* \#}$ & $30 \pm 3$ *\# & $29 \pm 4$ *\# & $19 \pm 1$ *\# \\
\hline NTR & $79 \pm 2 * \#$ & $22.3 \pm 0.3 *$ & $93 \pm 2$ *\# & $20.7 \pm 1.1 *$ & $95 \pm 4^{* \#}$ & $72 \pm 5$ *\# & $45 \pm 2$ *\# \\
\hline ATR & $57 \pm 2 * \#$ & $34.9 \pm 0.4 * \#$ & $71 \pm 6^{* \#}$ & $17.7 \pm 0.1 *$ & $83 \pm 5^{* \#}$ & $69 \pm 3$ *\# & $60 \pm 4^{* \#}$ \\
\hline \multirow[t]{2}{*}{ Fraction $P^{f}$} & - & - & $120 \pm 8^{*}$ & $14.1 \pm 0.2$ *\# & $34 \pm 2$ *\# & $65 \pm 4^{*}$ & $56 \pm 2 * \#$ \\
\hline & \multicolumn{7}{|c|}{ Standard phenolic and flavonoid compounds } \\
\hline Caffeic acid & - & - & $39.5 \pm 2.1$ & $0.013 \pm 0.06$ & $125 \pm 5$ & - & $45 \pm 1$ \\
\hline Gallic acid & - & - & $41.1 \pm 1.2$ & $0.022 \pm 0.01$ & $90 \pm 3$ & - & $28 \pm 2$ \\
\hline Quercetin & - & - & $1.52 \pm 0.12$ & $0.083 \pm 0.06$ & $105 \pm 3$ & - & $83 \pm 2$ \\
\hline Allopurinol & - & - & $0.13 \pm 0.01$ & - & - & - & - \\
\hline Diclofenac & - & - & - & - & - & $64 \pm 2$ & - \\
\hline
\end{tabular}

Data represent means \pm SEM of 3-6 independent experiments performed in triplicate. ${ }^{\text {a }}$ Values are expressed as mg of gallic acid equivalent (GAE) per gram of extract. ${ }^{b}$ RUE, rutin equivalent. ${ }^{c} \mathrm{IC}_{50}=$ concentration resulting in a $50 \%$ decrease in initial activity or concentration. ${ }^{d}$ Percentage values are indicated for compounds at $150 \mu \mathrm{g} / \mathrm{mL}$. e Percent inhibition values are indicated for compounds at $100 \mu \mathrm{g} / \mathrm{mL}$. ${ }^{\mathrm{f}}$ Fraction P composition: inophyllum P $(70 \%)$, tamanolide P $(20 \%)$ and calanolide B $(10 \%)$. Statistics: ${ }^{*} p<0.05$ vs. TO and ${ }^{\#} p<0.05$ vs. EtTO, by one-way ANOVA followed by Newman-Keuls test.

In Calophyllum oil, TPC was considered to reflect the content in reducing compounds, including benzoic acid derivatives [46], while its resinous fraction can contain up to $5 \%$ of polyphenols [47]. Analysis of the flavonoid content using $\mathrm{AlCl}_{3}$ complexation was reported to be mainly selective for flavonoids bearing $\mathrm{C}-3-\mathrm{OH}$ (flavonols) and $\mathrm{C}-5-\mathrm{OH}$ substituents, and for compounds bearing vicinal hydroxyl groups on the B ring, such as luteolin [48]. Biflavonoids have been also mentioned in TO [3]. Aluminium chloride complexation may also occur at other sites on flavonoids making more complex the interpretation of the TFC assay owing to the existence of several absorption wavelengths.

Altogether, the results here highlight that the resin part of TO is characterized by high levels of phenolic and flavonoid derivatives and that the ethanol-soluble extracts NTR and ATR would likely contain most of the functionalized secondary metabolites.

\subsection{In Vitro Antioxidant and Anti-Inflammatory Activities}

Antioxidant and anti-inflammatory activities of resin extracts and selected isolated compounds were evaluated by a series of assays relevant to ROS and ROS precursors that differ in their endpoints and mechanisms or implicated biological targets.

\subsubsection{Xanthine Oxidase Inhibition, Superoxide Quenching and MCC}

To limit oxidative stress, quenching and/or inhibiting $\mathrm{O}_{2}{ }^{\bullet-}$ formation could be of relevance for the medicinal use of $\mathrm{TO}$ and resins. $\mathrm{XO}$ inhibition by natural polyphenols, phenolic acids and flavonoids [30,49] or coumarins derivatives [8] has been reported. In the present work, ATR and NTR exhibited higher activities than EtTO (IC ${ }_{50} \sim 100 \mu \mathrm{g} / \mathrm{mL}$ ), with $\mathrm{IC}_{50}$ values ranging from 71 to $93 \mu \mathrm{g} / \mathrm{mL}$ (Table 1). Fraction $\mathrm{P}\left(\mathrm{IC}_{50} \sim 120 \mu \mathrm{g} / \mathrm{mL}\right.$ ) and the methanolic extracts MeTO and MeETR $\left(\mathrm{IC}_{50}>150 \mu \mathrm{g} / \mathrm{mL}\right.$ ) were significantly less potent, whereas the crude oil was poorly active $\left(\mathrm{IC}_{50} \sim 950 \mu \mathrm{g} / \mathrm{mL}\right)$ and the de-resinated DTO was inactive. It has been reported that $\mathrm{XO}$ inhibition is strongly enhanced by the presence of hydroxyl substituents at positions 6 and 7 of the coumarin benzo moiety, and possible interaction of coumarins with the molybdenum domain of the enzyme was investigated [8]. 
Among the coumarins identified in the TO extracts, some of them bear hydroxyl groups, but not in the optimal position to bind the $\mathrm{XO}$ active site. Hence, $\mathrm{XO}$ inhibition efficacy found here, i.e., ATR $>$ NTR $>$ EtTO $>$ Fraction $\mathrm{P}>\mathrm{MeTO} \approx \mathrm{MeETR}$, could be directly correlated to TFC. However, the possible effects of other metabolites not yet identified in the resins remain to be investigated.

Superoxide quenching capacity of TO and resins was evaluated in acetone by monitoring the inhibition of lucigenin luminescence from an allopurinol- $\mathrm{XO}_{2}{ }^{\bullet-}$ generator. Table 1 shows that extracts and fraction $\mathrm{P}$ that demonstrated the best $\mathrm{XO}$ inhibition property were also much stronger $\mathrm{O}_{2}{ }^{\bullet-}$ scavengers (i.e., 5-9-fold) as indicated by the lower $\mathrm{IC}_{50}$ values ranging from 14 to $25 \mu \mathrm{g} / \mathrm{mL}$.

The MCC value has been reported as an index of the ability to form complexes with $\mathrm{Fe}^{2+}$ to inhibit iron-induced damage [50]. Expectedly, the best activity in this assay was exhibited by phenolics- and flavonoids-enriched NTR and ATR at a level comparable to that of, e.g., quercetin.

\subsubsection{Anti-Inflammatory Properties of TO Extracts and Subfractions}

Inflammation plays a crucial role in the pathogenesis of several diseases and is characterized by the production of pro-inflammatory mediators and infiltration of various types of cells. Due to their antioxidant properties found above, it was interesting to investigate the potential of TO resins as in vitro anti-inflammatory agents on the two key enzymes, PTA and 15-LOX.

The results obtained in vitro in presence of serum albumin showed that the percentage of PTA inhibition by ATR, NTR and EtTO extracts ranged $62-72 \%$ and were nearly equal to the standard drug diclofenac (64\%) at the same concentration of $150 \mu \mathrm{g} / \mathrm{mL}$ (Table 1). Methanolic extracts were less potent (29-31\% inhibition), and the crude oil was found poorly active. Again, DTO was found to be inactive, showing that the resin is an essential component of TO biological activities.

In cells, 15-LOX catalyzes the oxidation of unsaturated fatty acids such as arachidonic acids to yield hydroperoxy fatty acids which could, in turn, mediate inflammation processes and trigger oxidative stress. It has been reported that flavonoids act efficiently as lipoxygenase inhibitors, both by scavenging peroxyl radicals and inhibiting lipid peroxidation [51].

Here, the standard quercetin induced a strong inhibition of $15-\mathrm{LOX}(83 \%$ at $100 \mu \mathrm{g} / \mathrm{mL})$, an effect potentially linked to the presence of hydroxyl groups in its structure, which could both interfere with the enzyme and scavenge free radicals [51]. Again, the two fractions NTR and ATR, rich in phenolic compounds and flavonoids, were found to be highly effective regarding enzyme inhibition (45-60\%). Interestingly, the fraction P containing 70\% of inophyllum P was also found to be highly effective against 15-LOX (56\% inhibition), a result in line with previous findings on inophyllums $\mathrm{D}$ and $\mathrm{H}$ isolated from Calophyllum symingtonianum [52]. Inophyllum P (see Figure 1), as well as inophyllums D and H, contain an $\mathrm{OH}$ group in its structure.

\subsubsection{DPPH and TRAP Assays}

The DPPH assay, an index of global free radical reducing activity, was performed in dichloromethane. The TRAP assay, which evaluates the capacity to scavenge peroxyl radicals, was performed in aqueous/acetone medium. The results are reported in Table 2.

Despite sesame oil being relatively rich in antioxidants, including sesamol [21,22], TO was found to be more active in both DPPH and TRAP assays, suggesting that the oil contains more lipophilic antioxidants than sesame oil. Moreover, the antioxidant properties of TO may rely mainly on the resin part since the de-resinated DTO was found to be inactive. Remarkably, the crude oil was found $\sim 30$-fold less active than resin extracts and subfractions, with ATR being the most efficient. The DPPH scavenging capacity of the secondary metabolites isolated from NTR and ATR was also evaluated. In this test, the compounds were as follows: strongly active (inophyllum $\mathrm{P}>$ fraction $\mathrm{P}$ ), moderately active (inophyllum E > inocalophyllin B > inophyllum C > tamanolide D), slightly active 
(calophyllolide $\approx$ calanolide GUT $70>$ calanolide A) and inactive (12-oxocalanolide A, calanolide D). Inophyllum P, bearing a chromanol hydroxyl group on the C-12 of the D-ring, is 20-30 times more active than inophyllums $E$ and $C$, which lack this function. However, these latter exhibited better activity than calanolide D and 12-oxocalanolide A.

Table 2. Antioxidant capacities of Tamanu oil resin extracts, neutral (NTR) and acidic (ATR) subfractions and selected isolated metabolites by the DPPH and TRAP assays.

\begin{tabular}{|c|c|c|c|c|c|}
\hline Compounds & DPPH & TRAP & $\%$ by Weight in $\mathrm{TO}^{\mathrm{a}}$ or EtTO ${ }^{\mathrm{b}}$ & $\%$ by Weight in Subfractions & $A \log P^{c}$ \\
\hline Oils and fractions & $\mathrm{IC}_{50}(\mathrm{mg} / \mathrm{mL})^{\mathrm{d}}$ & $\mathrm{TE}^{\mathrm{e}}$ & & & \\
\hline TO & $432 \pm 1.1$ & $67 \pm 11$ & & & \\
\hline Sesame oil & $668 \pm 1.2 *$ & $28 \pm 6^{*}$ & & & \\
\hline DTO & $>800 *$ & $\sim 0$ & $\sim 60$ & & \\
\hline МетO & $40.2 \pm 1.1 * \#$ & $112+14$ *\# & $18.2^{\mathrm{a}}$ & & \\
\hline EtTO & $26.1 \pm 0.1$ & $280 \pm 12 *$ & $15.7^{\mathrm{a}}$ & & \\
\hline NTR & $10.2 \pm 1.1 * \#$ & $172+14$ *\# & $50.0^{\mathrm{b}}$ & & \\
\hline ATR & $5.1 \pm 0.4 * \#$ & $340 \pm 11 * \#$ & $48.3^{b}$ & & \\
\hline NTR metabolites & $\mathrm{IC}_{50}(\mu \mathrm{M})$ & $\mathrm{TE}$ & & $\%$ by weight in NTR & $A \log P$ \\
\hline Inophyllum $\mathbf{P}$ & $26.2 \pm 3.1$ & $4.11 \pm 0.10$ & 0.05 & 0.121 & 4.56 \\
\hline Fraction $P f$ & $40.9 \pm 1.1$ & $3.57 \pm 0.39$ & $0.04^{\mathrm{e}}$ & 0.102 & ND $g$ \\
\hline Tamanolide D & $779 \pm 7$ & $1.36 \pm 0.20$ & 0.02 & 0.038 & 4.45 \\
\hline Inophyllum C & $701 \pm 9$ & $0.21 \pm 0.04$ & 0.042 & 0.078 & 4.55 \\
\hline Inophyllum E & $481 \pm 7$ & $0.91 \pm 0.04$ & 0.014 & 0.029 & 4.55 \\
\hline Calophyllolide & $\sim 890$ & $0.48 \pm 0.08$ & 0.019 & 0.038 & 5.3 \\
\hline Calanolide GUT 70 & $\sim 900$ & $0.30 \pm 0.03$ & 0.024 & 0.048 & 4.96 \\
\hline Calanolide A & $\sim 950$ & $0.40 \pm 0.02$ & $<0.02$ & 0.021 & 4.18 \\
\hline Calanolide D & $>1000$ & ND & 0.007 & 0.015 & 4.31 \\
\hline 12-Oxocalanolide A & $>1000$ & ND & 0.005 & 0.011 & 4.31 \\
\hline ATR metabolites & $\mathrm{IC}_{50}(\mu \mathrm{M})$ & TE & & $\%$ by weight in ATR & $A \log P$ \\
\hline Inocalophyllin B & $583 \pm 17$ & $1.07 \pm 0.06$ & 0.063 & 0.2 & 4.7 \\
\hline Standards & $\mathrm{IC}_{50}(\mu \mathrm{M})$ & $\mathrm{TE}$ & & & $\mathrm{A} \log \mathrm{P}$ \\
\hline Trolox & $21.2 \pm 0.8$ & 1 & & & 2.75 \\
\hline Sesamol & $66.9 \pm 3.1$ & $1.34 \pm 0.09$ & & & 0.89 \\
\hline BHA & $94.9 \pm 6.1$ & $3.46 \pm 0.20$ & & & 4.14 \\
\hline Caffeic acid & $18.1 \pm 0.21$ & $2.98 \pm 0.14$ & & & 2.6 \\
\hline Quercetin & $14.1 \pm 0.21$ & $6.31 \pm 0.24$ & & & 1.81 \\
\hline
\end{tabular}

Data represent the mean \pm SEM of 3-6 independent experiments performed in triplicate. ${ }^{a, b}$ Extracts and metabolites content are expressed as a percentage by weight (in $\mathrm{g} / 100 \mathrm{~g}$ ) of ${ }^{\mathrm{a}} \mathrm{TO}$ or ${ }^{\mathrm{b}}$ EtTO. ${ }^{\mathrm{c}}$ Determined using the Virtuel Computational Chemistry Laboratory software at: ALOGPS 2.1 homepage. Available online: (http://www.vcclab.org/lab/alogps/). (accessed on 3 July 2020) ${ }^{d}$ IC $_{50}$ defined as the concentration resulting in a 50\% decrease in the initial DPPH concentration. ${ }^{e}$ Data are given in Trolox equivalent (TE). For oils and resin fractions, the reported TE values represent the activity of a solution at $1 \mathrm{~g} / \mathrm{L}$ relative to $1 \mu \mathrm{M}$ Trolox. For metabolites and standards compounds, TE values represent the activity of a $1 \mu \mathrm{M}$-solution relative to $1 \mu \mathrm{M}$ Trolox. ${ }^{\mathrm{f}}$ Inophyllum $\mathrm{P}$ accounts for $\sim 70 \%$ in fraction P. g ND, not determined. Statistics: ${ }^{*} p<0.05$ vs. TO and ${ }^{\#} p<0.05$ vs. EtTO, by one-way ANOVA followed by Newman-Keuls test.

In the TRAP assay, all extracts, especially ATR, were found to be much more efficient than crude TO, which yielded at least 4-fold lower TE values. Among the isolated compounds a strong antioxidant activity was found for inophyllum $\mathrm{P}$ and Fraction $\mathrm{P}$, followed by tamanolide $\mathrm{D}$ and inocalophyllin $\mathrm{B}$. The other metabolites were found to be poorly active in the assay, unrelated to the calculated lipophilicities (as AlogP values). Figure 2 shows the correlation of the measured $\triangle \mathrm{AUC}$ with the sample concentration in the TRAP assay for seven selected compounds and fraction $\mathrm{P}$, evidencing the strong capacities of inophyllum $\mathrm{P}$, fraction $\mathrm{P}$ and inocalophyllin $\mathrm{B}$ in peroxyl radicals scavenging. This has been proposed to be a possible antioxidant mechanism of coumarins besides enzyme inhibition and chelation of pro-oxidant catalytic metals [53]. 


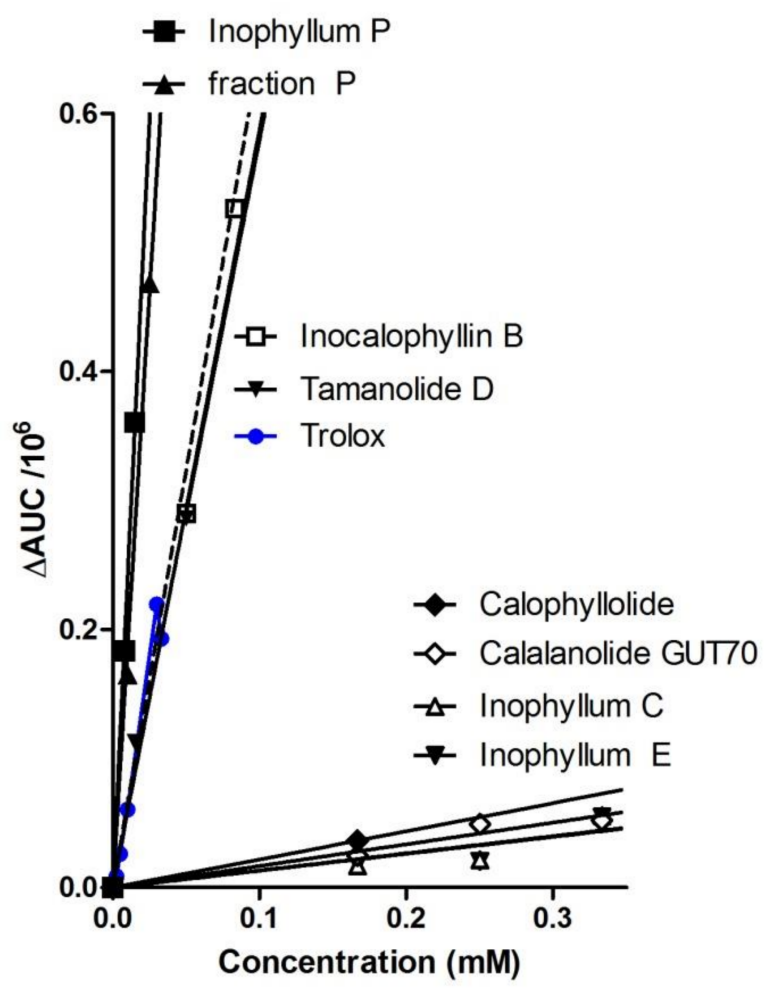

Figure 2. Superoxide scavenging capacity of TO extracts metabolites by TRAP luminescence assay. Linear correlations plots are expressed as area under the curve ( $\triangle \mathrm{AUC}$ ) versus compounds concentrations. In fraction $\mathrm{P}$, inophyllum $\mathrm{P}$ accounts for $\sim 70 \%$ in weight.

Several coumarins extracted from C. inophyllum exhibited rather strong antioxidant properties in the TRAP and DPPH assays despite they do not bear a catechol structure nor phenol groups, both structural patterns known to confer free radical scavenging power [53,54]. Interestingly, two structural patterns occur in these active compounds: (i) a 4-chromanol moiety, such as in inophyllum P, tamanolide D, calanolide A and tamanolide $\mathrm{D}$ contained in fraction $\mathrm{P}$, and (ii) other potential radical scavenging groups such as nonphenolic conjugated $\mathrm{OH}$ groups (in inocalophyllin B) or $\alpha, \beta$-unsaturated ketones (present in each coumarin scaffold). The high activity observed for inophyllum $\mathrm{P}$, close to that of the phenolic standards (Table 2) and of fraction P, containing tamanolide $\mathrm{P}$, calanolide $\mathrm{B}$ and inophyllum $\mathrm{P}$ (all three compounds bearing the chromanol part) could rely on two frameworks, the chromanol and the coumarin patterns in the structure. Therefore, inophyllum $\mathrm{P}$ is about four times more efficient than Trolox in the TRAP assay. Inocalophyllin B also exerted a significant TRAP activity, which could be related to the presence of (i) the ketone conjugated $\mathrm{OH}$ group due to the saponification of the lactone B-ring, and (ii) two prenylated side chains [54].

Inophyllums C and E, calophyllolide and calanolide GUT70, bearing a chromanone moiety instead of a chromanol, are weakly active. The DPPH inactive calanolide D and 12-oxocalanolide $\mathrm{A}$, not featuring those potential antioxidant patterns and bearing a chromanone moiety, have not been tested in the TRAP assay.

Given all the above aspects dealing with ROS inhibition, it has been demonstrated here that extracting crude TO with an appropriate solvent such as ethanol is a very powerful route toward a series of EtTO-derived fractions enriched in compounds conferring substantially increased antioxidant/free radical scavenging and anti-inflammatory capacities. Among these, neutral resin NTR contains the major part of the identified molecules, inophyllum P being one of the most abundant (about 16\% of EtTO isolated products) and the most efficient in DPPH and TRAP assays. In this latter regard, the acidic resin ATR was 
even more interesting because of the presence of the strong antioxidant inocalophyllin B in a relatively high yield (about $21 \%$ of EtTO-isolated products).

\subsection{Antimicrobial and Anti-Mycobacterial Activity}

The antimicrobial activity of TO fractions was first screened against $S$. aureus using the disk diffusion assay, with oxacillin used as a positive control. The results are reported in Table 3.

Table 3. Antimicrobial (S. aureus) and antimycobacterial (M. tuberculosis H37 RV) activities and cytotoxicity on murine 3T3 fibroblasts and human lung carcinoma cells A549 of Tamanu oil (TO) extracts, subfractions and selected metabolites.

\begin{tabular}{|c|c|c|c|c|}
\hline \multirow{3}{*}{ Compounds } & \multicolumn{4}{|c|}{ Microorganisms } \\
\hline & S. aureus & M. tuberculosis & 3T3 Fibroblasts & A549 Cells \\
\hline & Diameter $(\mathrm{mm})^{a}$ & $\operatorname{MIC}(\mu \mathrm{g} / \mathrm{mL})^{b}$ & $\mathrm{IC}_{50}(\mu \mathrm{g} / \mathrm{mL})^{\mathrm{c}}$ & $\mathrm{IC}_{50}(\mu \mathrm{g} / \mathrm{mL})$ \\
\hline TO & $<5$ & $>150$ & $\sim 20$ & $\sim 10$ \\
\hline МетO & $<5$ & $>150$ & $120 \pm 3$ & $50.1 \pm 2.6$ \\
\hline EtTO & $13 \pm 1^{*}$ & $17.3 \pm 0.2 *$ & $108 \pm 4$ & $25.6 \pm 0.9 *$ \\
\hline NTR & $23 \pm 3$ *\# & $2.8 \pm 0.3^{* \#}$ & $80 \pm 8$ & $17.7 \pm 2.1$ *\# \\
\hline ATR & $19 \pm 2 * \#$ & $10.2 \pm 0.5^{* \#}$ & $150 \pm 6$ & $94.7 \pm 3.3^{* \#}$ \\
\hline Fraction $\mathbf{P} d$ & $19 \pm 2 * \#$ & $7.5 \pm 0.2$ *\# & $89 \pm 8^{* \#}$ & $25.5 \pm 2.1 * \#$ \\
\hline Inophyllum $\mathbf{P}$ & $17 \pm 1 * \#$ & $5.7 \pm 0.3$ *\# & $92 \pm 4^{*}$ & $11.3 \pm 0.6^{*}$ \\
\hline Inophyllum E & $14 \pm 2 *$ & $>15$ & $120 \pm 9 *$ & $44.8 \pm 2.2 * \#$ \\
\hline Tamanolide D & $12 \pm 2^{*}$ & $5.1 \pm 0.3^{* \#}$ & $46 \pm 5 * \#$ & $9.3 \pm 1.2 *$ \\
\hline Calophyllolide & $19 \pm 3^{* \#}$ & $>15$ & $49 \pm 4^{* \#}$ & $3.1 \pm 0.9$ *\# \\
\hline 12-oxo-Calanolide A & $18 \pm 2 * \#$ & $>15$ & $36 \pm 8$ *\# & $1.9 \pm 0.1 * \#$ \\
\hline Calanolide A & $14 \pm 1 *$ & $4.1 \pm 0.3^{* \#}$ & $52 \pm 8$ *\# & $8.2 \pm 1.7$ *\# \\
\hline Inocalophyllin B & $20 \pm 2 *$ & $>15$ & $41 \pm 5$ *\# & $4.2 \pm 1.3^{* \#}$ \\
\hline Oxacillin & $30 \pm 1$ & $\mathrm{ND}^{\mathrm{e}}$ & ND & ND \\
\hline Streptomycin & ND & $0.4 \pm 0.1$ & ND & ND \\
\hline
\end{tabular}

Results are expressed as means \pm SEM of 3 independent experiments made in triplicate. ${ }^{\text {a }}$ Antimicrobial activity was evaluated by measuring the diameter of the zone of inhibition impregnated at $20 \mu \mathrm{g} / \mathrm{disk}$. ${ }^{\mathrm{b}} \mathrm{MIC}$ is defined as the minimum inhibitory concentration. ${ }^{\mathrm{c}} \mathrm{IC}_{50}$ is defined as the concentration of compound resulting in $50 \%$ viability after $48 \mathrm{~h}$ and calculated from concentration-response curves. ${ }^{\mathrm{d}}$ Fraction $\mathrm{P}$ contains $\sim 70 \%$ in weight of

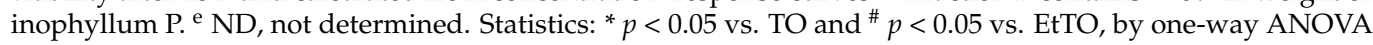
followed by Newman-Keuls test.

At $20 \mu \mathrm{g}$ per disc, all ethanol-derived extracts and isolated fractions exhibited significantly better antimicrobial activities than $\mathrm{TO}$ and MeTO, which were found inactive. The most active fractions were NTR and ATR and, to a lesser extent, EtTO, however, still to a notably less efficient than oxacillin. From the NTR fraction, inophyllum P and fraction P exhibit significant activity as well as calophyllolide and 12-oxocalanolide A. Inocalophyllin B from ATR fraction was also found active against $S$. aureus, and its resulting antimicrobial was roughly similar to that of ATR. The antimicrobial efficiency of several other constituents from the genus Calophyllum has been reported against $S$. aureus but not against other microorganisms [11]. This point remains to be further investigated using the present $\mathrm{TO}$ resins and fractions on several other strains.

The activity of compounds against strain H37Rv of $M$. tuberculosis was evaluated by determining the MIC defined as the lowest concentration inhibiting at least $99 \%$ of the bacterial population present in the medium at the beginning of the assay. The results indicated that EtTO, ATR, and especially NTR and pyranocoumarins exhibited significant antimicrobial activity. Interestingly, ATR was found less cytotoxic than EtTO, NTR and all other compounds, including inocalophyllin B, both on cancer A549 cells than normal 3T3 fibroblasts. Likely because of its high lipophilicity and the weak proportion of bioactive constituents in its lipid phase, TO was found both cytotoxic at low concentrations and poorly efficient as antimicrobial agent.

Coumarin has been shown to exhibit antimicrobial activity against Gram-positive and Gram-negative bacterial strains, a property attributed to its aromaticity and lipophilicity, which can allow it to cross the bacterial wall and interact with the cell membrane [55-57]. 
The presence of a pyran ring in the coumarin structure does not necessarily enhance the antibacterial activity, but the presence of $\mathrm{OH}$ groups might be favorable. On the other hand, phenolic compounds often exhibit antimicrobial properties, and among their possible mechanisms of action, it has been suggested that the bacterial membrane potential can be destabilized by $\mathrm{OH}$ groups [58]. Metal deprivation or enzyme inactivation by phenolics have also been evoked [59]. Here, NTR, which is rich in phenolic derivatives as indicated by its TPC value (Table 1) and gathers amounts of $\mathrm{OH}$-bearing pyranocoumarins (i.e., inophyllum $\mathrm{P}$, tamanolides $\mathrm{D}$ and $\mathrm{P}$, and calanolide $\mathrm{A}$ ) exhibited a higher antibacterial efficiency against both S. aureus and M. tuberculosis than ATR. This latter fraction contains, however, the prenylated inocalophyllin B, which appears to be mainly responsible for ATR activity against $S$. aureus. Then, even if bactericidal activity can also involve ROS production [55], bioactive molecules can share some structural features supporting both antioxidant and antibacterial activities through different mechanisms [60].

Owing to their biological properties, TO resin extracts could lead to further development of new sources of naturally occurring anti-infectious agents.

\subsection{Biological and EPR Evidence of the Protective Effects of Tamanu Oil Derivatives against Oxidative Stress}

The protective effect of resins and metabolites on 3T3 fibroblasts undergoing oxidative stress was evaluated using three indexes: (i) the amount of cytosolic LDH released from damaged cells, (ii) cell viability using the neutral red assay and (iii) oxidative stress status through cellular MDA-TBA formation. Oxidative stress was induced by exposing the cells for $4 \mathrm{~h}$ to $0.4 \mathrm{mM} t \mathrm{BuOOH}$, a concentration close to its reported $\mathrm{IC}_{50}$ value in fibroblasts [35]. At the non-cytotoxic dose of $15 \mu \mathrm{g} / \mathrm{mL}$ (Table 3), the resins EtTO, NTR, ATR and Fraction $\mathrm{P}$ significantly prevented LDH leakage in culture supernatants, improved cell viability and protected cells against MDA formation (Figure 3). Despite its low solubility in aqueous medium, the flavonoid antioxidant quercetin at $3 \mu \mathrm{g} / \mathrm{mL}$ afforded similar protection against cell damage and oxidative stress but only poorly prevented the known $t \mathrm{BuOOH}$ induced ROS dependent apoptotic effect [35]. The finding that treatment with the crude oil induced a slight LDL leakage illustrates the benefit of using TO derived resins rather than TO itself for best protecting the cells.

Finally, the photo-protective efficacy of resins in simple ointment-based applications was investigated on rat skin slices using a model widely used in pharmacological and dermatology research. Crude TO, EtTO and derived resins were applied topically onto the skin slices as olive oil emulsions [16] before a phototoxic dose of UV light was applied for $1 \mathrm{~h}$.

First, spin trapping was applied, an indirect detection technique in which transient free radicals are allowed to form EPR-detectable adducts with nitrones for the purposes of identification and quantification [36]. When samples from untreated post-irradiated skin slices were dark-incubated for $15 \mathrm{~min}$ in a milieu supplemented with the nitrone DEPMPO $(15 \mathrm{mM})$, strong EPR signals were detected in the supernatant, the simulation of which was consistent with a mixture of DEPMPO-OOH ( 80\%) and DEPMPO-OH $(\sim 20 \%)$ (upper trace in Figure 4A). Almost complete inhibition of this signal by a SOD $(10 \mathrm{U} / \mathrm{mL}$ ) + CAT $\left(5000 \mathrm{U} / \mathrm{mL}\right.$ ) mixture (Figure $4 \mathrm{~A}$, middle trace) suggested $\mathrm{O}_{2}{ }^{\bullet-}$ was the primary trapped radical, although other reactive species such as singlet oxygen (a ROS not yielding DEPMPO adducts) are known to form in UV-irradiated cells [22]. Moreover, although direct scavenging of $\mathrm{HO} \bullet$ cannot be excluded, DEPMPO-OH adducts seen in Figure 4A may have originated from other $\mathrm{HO} \bullet$-independent mechanisms, such as metal-ion-catalyzed nucleophilic addition of water to the nitrone or reduction of DEPMPO-OOH by glutathione peroxidase [36]. Consistent with their global antioxidant properties investigated above, TO and all derivatives were found to be significant inhibitors of DEPMPO spin adduct formation in post-irradiated skin (as shown for NTR in Figure 4A, lower trace), with a marked better effect seen for EtTO and resins versus TO (Figure 4B).

Expectedly, a similar inhibition pattern among Tamanu compounds was observed with the lipid peroxidation status of irradiated cells, i.e., MDA-TBA content (Figure 4C). 
Indeed, wound treatment, either in acute or chronic cases, is one of the most important applications of TO in dermatology [1,2], and it has been found that C. inophyllum oils from French Polynesian are among the most efficient [15]. Wound healing is a complex phenomenon, consisting of several successive steps, including haemostasis, inflammation, cell proliferation and remodeling. Presently, it is admitted that ROS are involved in most of these steps, with a crucial role in signaling and antimicrobial action. However, these beneficial effects must be kept under the control of the cell antioxidant pool. In impaired wound healing, such as ulcers occurring in diabetes, venous insufficiency or radiotherapy burns, the healing process is blocked at the inflammatory stage and does not evolve to final cicatrization. In such cases, oxidative stress has been evidenced together with disturbed endogenous antioxidant profile $[61,62]$. In topical application uses on the skin or mucous membrane wounds, new TO resins could offer a protective coating with anti-inflammatory (tamanolide P), antioxidant (inocalophyllin B, inophyllums P, C and E, and tamanolide D), anti-mycobacterial and antimicrobial (calophyllolide, calanolide A, inophyllums $\mathrm{P}$ and E), and fibroblast protective capacities, which can be attributed to ATR and NTR secondary metabolites.

A

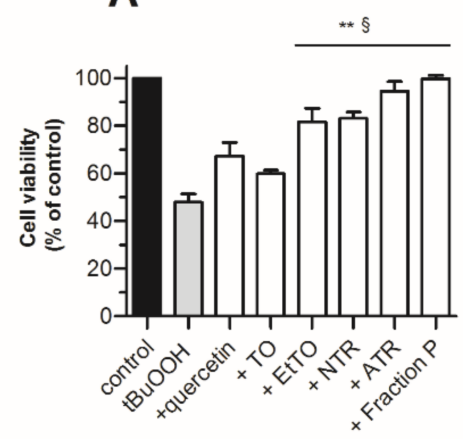

B

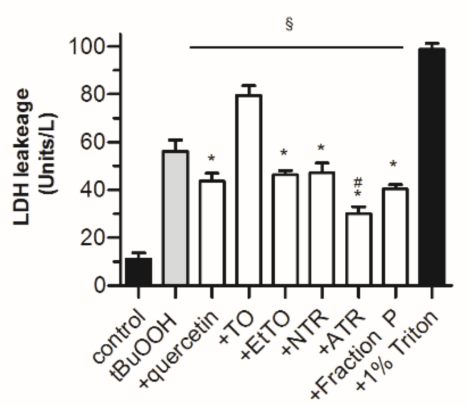

C

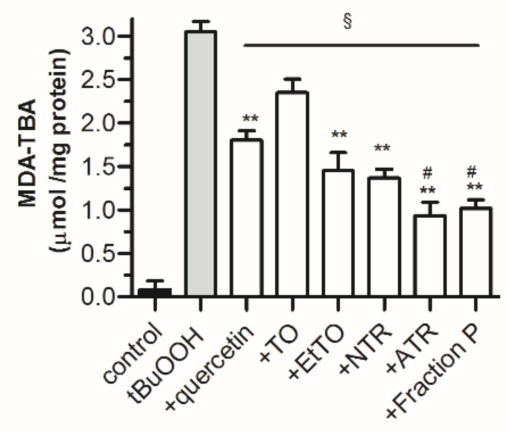

Figure 3. Protective effect of TO extracts and metabolites against $t \mathrm{BuOOH}$-induced cytotoxicity in 3 T3 fibroblasts $\left(1 \times 10^{6}\right.$ cells $\left./ \mathrm{mL}\right)$. Cell viability and oxidative stress were assessed after $4 \mathrm{~h}$ of incubation in the absence or presence of test compounds at $15 \mu \mathrm{g} / \mathrm{mL}$, by (A) LDH leakage in culture supernatant, (B) neutral red-based viability assay, (C) MDA-TBA levels. Quercetin was used at $3 \mu \mathrm{g} / \mathrm{mL}$. Values represent means $\pm \operatorname{SEM}(n=8)$. Statistics: ${ }^{*} p<0.05$ and ${ }^{* *} p<0.01$ vs. TO, ${ }^{\#} p<0.05$ vs. EtTO and ${ }^{\S} p<0.01$ vs. $t \mathrm{BuOOH}$, by one-way ANOVA $(p<0.01)$ followed by Newman-Keuls test. 
A
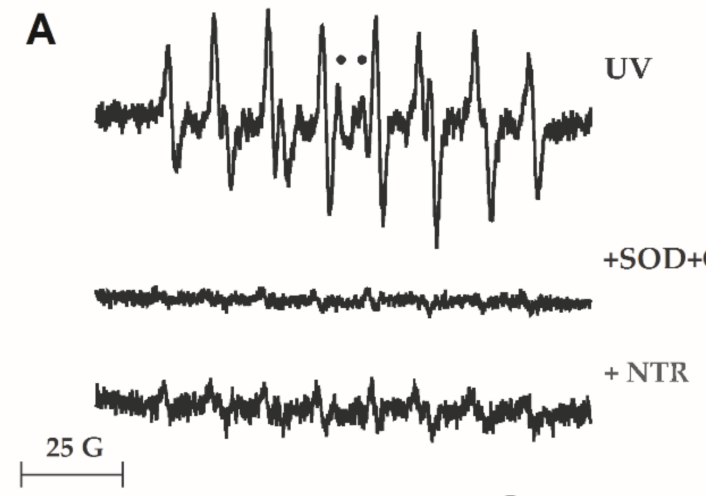

B

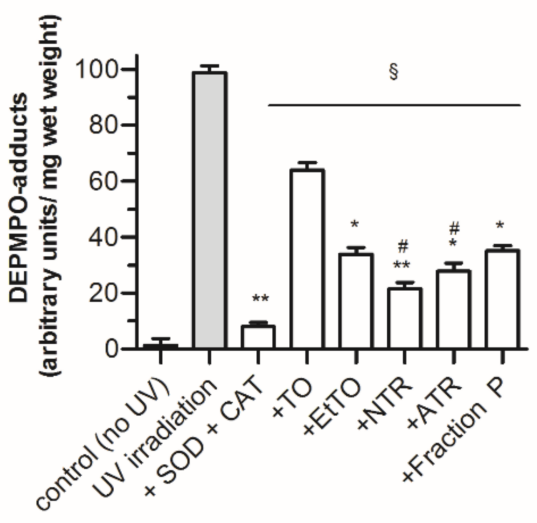

C

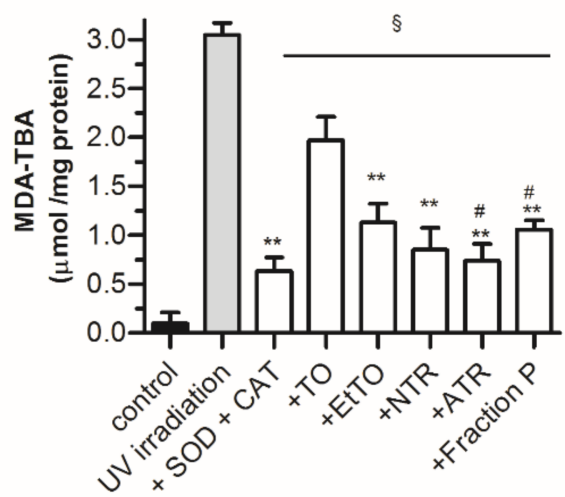

Figure 4. Protective effect of TO extracts and metabolites against UV irradiation $(1 \mathrm{~h})$-induced damage in rat skin slices. (A) Typical electron paramagnetic resonance (EPR) signals of mixtures of DEPMPO-OOH + DEPMPO-OH in the supernatants of post-irradiated skin slices incubated with aqueous DEPMPO (15 mM). SOD, superoxide dismutase $(10 \mathrm{U} / \mathrm{mL})$; CAT, catalase $(5000 \mathrm{U} / \mathrm{mL})$; NTR, neutral resin subfraction; •, DEPMPO-OH central lines. (B) Total DEPMPO adducts levels. (C) MDA-TBA levels. Values represent means \pm SEM $(n=8)$. Statistics: ${ }^{*} p<0.05$ and ${ }^{* *} p<0.01$ vs. TO, ${ }^{\#} p<0.05$ vs. EtTO and $\S p<0.01$ vs. UV-irradiated untreated slices, by one-way ANOVA $(p<0.01)$ followed by Newman-Keuls test.

\section{Conclusions}

Here, the biological properties of ethanol-soluble fractions of TO and their corresponding pyranocoumarin constituents were evidenced in a series of in vitro and ex vivo tests. The results demonstrate that (i) the main biological activity of TO can be attributed to the resin part rich in pyranocoumarins and other phenolic and flavonoid derivatives to be determined further; (ii) new resin fractions prepared here from TO extraction are easy to handle and showed significantly better antioxidant, enzyme inhibition, anti-inflammatory and antimicrobial activities than the starting crude TO material, (iii) the improved solubility of these new fractions could be of interest for further development of new pharmacological applications from natural and renewable sources.

Supplementary Materials: The following are available online at https:/ / www.mdpi.com/2076-392 1/10/2/199/s1, Figures S1-S18, ${ }^{1}$ H-NMR and ${ }^{13}$ C-NMR spectra, and MS analysis of isolated and identified phytoconstituents of Tamanu oil, and the structure of detected DEPMPO spin adducts.

Author Contributions: Conceptualization, S.P. and P.R.; methodology, M.C. (Mathieu Cassien), A.M., A.A., E.R. and S.P.; validation, S.T.-L., M.C. (Marcel Culcasi) and S.P.; formal analysis, S.T.-L., A.M., M.C. (Marcel Culcasi) and S.P.; investigation, M.C. (Mathieu Cassien), A.M., A.A., E.R., G.H. and S.P.; resources, J.-P.B., P.R. and S.P.; data curation, G.H., A.M., S.T.-L. and S.P.; writing-original draft preparation, P.R., A.M. and S.T.-L.; writing-review and editing, M.C. (Marcel Culcasi) and S.P.; 
supervision, S.P.; project administration, S.P.; funding acquisition, S.T.-L., and S.P. All authors have read and agreed to the published version of the manuscript.

Funding: This work was funded by the MNERT (CNRS-UMR 7273, Institut de Chimie Radicalaire). Part of this study (antioxidant and biological assays) was supported by fundings of the Agence Nationale de la Recherche, France (ANR JCJC MitoDiaPM-N ANR-17-CE34-0006-01).

Institutional Review Board Statement: The study was approved by the Ethics Committee of Provence (CEEA 14) at Aix Marseille University and the French Ministry of National Education, Higher Education and Research (protocol code APAFIS\#2396-2015112910476544, date of approval: 03/01/2016).

Informed Consent Statement: Not applicable.

Data Availability Statement: Not applicable Please refer to suggested Data Availability Statements in section "MDPI Research Data Policies" at https:/ / www.mdpi.com/ethics.

Acknowledgments: The authors thank T. Leu and H. Rahmouni for their valuable experimental contributions.

Conflicts of Interest: The authors declare no conflict of interest.

\begin{abstract}
Abbreviations
AAPH, 2,2'-diazobis(2-amidinopropane)dihydrochloride; ATR, acidic fraction; DEPMPO, 5(diethoxyphosphoryl)-5 methyl-1-pyrroline N-oxide; DMEM, Dulbecco's modified eagle's medium; DPPH, 1,1-diphenyl-2-picrylhydrazyl; EPR, electron paramagnetic resonance; EtTO, Tamanu oil ethanolic extract; LDH, lactate dehydrogenase; LPO, lipoxygenase; MDA, malondialdehyde; MeETR, Tamanu resin methanolic extract; MeTO, Tamanu oil methanolic extract; MTT, 3-(4,5-dimethylthiazol-2-yl)-2,5-diphenyltetrazolium bromide; NTR, neutral fraction; PBS, phosphate-buffered saline; PTA, proteinase K; ROS, reactive oxygen species; TBA, 2thiobarbituric acid; TFC, total flavonoid content; TO, Tamanu oil; TPC, total phenolic content.
\end{abstract}

\title{
References
}

1. Gupta, S.; Gupta, P. The Genus Calophyllum inophyllum: Review of Ethnomedicinal Uses, Phytochemistry and Pharmacology. In Bioactive Natural Products in Drug Discovery; Singh, J., Meshram, V., Gupta, M., Eds.; Springer Nature Singapore Private Limited: Singapore, 2020; Chapter 5; pp. 215-242. [CrossRef]

2. Oo, W.M. Pharmacological properties of Calophyllum inophyllum-Updated review. J. Photochem. Photobiol. C Photochem. Rev. 2018, 2, 28-32. [CrossRef]

3. Said, T.; Dutot, M.; Martin, C.; Beaudeux, J.L.; Boucher, C.; Enee, E.; Baudouin, C.; Warnet, J.M.; Rat, P. Cytoprotective effect against UV-induced DNA damage and oxidative stress: Role of new biological UV filter. Eur. J. Pharm. Sci. 2007, 30, 203-210. [CrossRef] [PubMed]

4. Balogun, O.S.; Ogunniyi, D.R. Chemical and biological assessment of Callophyllum inophylum (Linn) seed oil. Pharmacol. Online 2012, 3, 58-62.

5. Crane, S.; Aurore, G.; Joseph, H.; Mouloungui, Z.; Bourgeois, P. Composition of fatty acids triacylglycerols and unsaponifiable matter in Calophyllum calaba L. oil from Guadeloupe. Phytochemistry 2005, 66, 1825-1831. [CrossRef] [PubMed]

6. Kashman, Y.; Gustafson, K.R.; Fuller, R.W.; Cardellina, J.H., II; McMahon, J.B.; Currens, M.J.; Buckheit, R.W., Jr.; Hughes, S.H.; Cragg, G.M.; Boyd, M.R. The calanolides, a novel HIV-inhibitory class of coumarin derivatives from the tropical rainforest tree, Callophyllum lanigerum. J. Med. Chem. 1992, 35, 2735-2743. [CrossRef]

7. Spino, C.; Dodier, M.; Sotheeswaran, S. Anti-HIV coumarins from Calophyllum seed oil. Bioorg. Med. Chem. Lett. 1998, 8, 3475-3478. [CrossRef]

8. $\quad$ Lin, H.C.; Tsai, S.H.; Chen, C.S.; Chang, Y.C.; Lee, C.M.; Lai, Z.Y.; Lin, C.M. Structure-activity relationship of coumarin derivatives on xanthine oxidase-inhibiting and free radical-scavenging activities. Biochem. Pharmacol. 2008, 75, 1416-1425. [CrossRef]

9. Ishikawa, T. Anti-HIV-1 active Calophyllum coumarins: Distribution, chemistry, and activity. Heterocycles 2000, 53, 453-474. [CrossRef]

10. Kawazu, K.; Ohigashi, H.; Takahashi, N.; Mitsui, T. Piscicidal constituents of Calophyllum inophyllum. Bull. Inst. Chem. Res. Kyoto Univ. 1992, 50, 160-167. [CrossRef]

11. Yimdjo, M.C.; Azebaze, A.G.; Nkengfack, A.E.; Meyer, A.M.; Bodo, B.; Fomum, Z.T. Antimicrobial and cytotoxic agents from Calophyllum inophyllum. Phytochemistry 2004, 65, 2789-2795. [CrossRef]

12. Xu, Z.Q.; Barrow, W.W.; Suling, W.J.; Westbrook, L.; Barrow, E.; Lin, Y.M.; Flavin, M.T. Anti-HIV natural product (+)-calanolide A is active against both drug-susceptible and drug-resistant strains of Mycobacterium tuberculosis. Bioorg. Med. Chem. 2004, 12, 1199-1207. [CrossRef] [PubMed] 
13. Itoigawa, M.; Ito, C.; Tan, H.T.W.; Kuchide, M.; Tokuda, H.; Nishino, H.; Furukawa, H. Cancer chemopreventive agents, 4-phenylcoumarins from Calophyllum inophyllum. Cancer Lett. 2001, 169, 15-19. [CrossRef]

14. Prasad, J.; Shrivastava, A.; Khanna, A.K.; Bhatia, G.; Awasthi, S.K.; Narender, T. Antidyslipidemic and antioxidant activity of the constituents isolated from the leaves of Calophyllum Inophyllum. Phytomedicine 2012, 19, 1245-1249. [CrossRef] [PubMed]

15. Léguillier, T.; Lecsö-Bornet, M.; Lémus, C.; Rousseau-Ralliard, D.; Lebouvier, N.; Hnawia, E.; Nour, M.; Aalbersberg, W.; Ghazi, K.; Raharivelomanana, P.; et al. The wound healing and antibacterial activity of five ethnomedical Calophyllum inophyllum oils: An alternative therapeutic strategy to treat infected wounds. PLoS ONE 2015, 10, e0138602. [CrossRef] [PubMed]

16. Ansel, J.L.; Lupo, E.; Mijouin, L.; Guillot, S.; Butaud, J.F.; Ho, R.; Lecellier, G.; Raharivelomanana, P.; Pichon, C. Biological activity of Polynesian Calophyllum inophyllum oil extract on human skin cells. Planta Med. 2016, 82, 961-966. [CrossRef] [PubMed]

17. Métoyer, B.; Lebouvier, N.; Hnawia, E.; Herbette, G.; Thouvenot, L.; Asakawa, Y.; Nour, M.; Raharivelomanana, P. Chemotypes and biomarkers of seven species of new Caledonian liverworts from the Bazzanioideae subfamily. Molecules 2018, $23,1353$. [CrossRef] [PubMed]

18. Leu, T.; Raharivelomanana, P.; Soulet, S.; Bianchini, J.P.; Herbette, G.; Faure, R. New tricyclic and tetracyclic pyranocoumarins with an unprecedented C-4 substituent. Structure elucidation of tamanolide, tamanolide D and tamanolide P from Calophyllum inophyllum of French Polynesia. Magn. Reson. Chem. 2009, 47, 989-993. [CrossRef]

19. Ginigini, J.; Lecellier, G.J.; Nicolas, M.; Nour, M.; Hnawia, E.; Lebouvier, N.; Herbette, G.; Lockhart, P.; Raharivelomanana, P. Chemodiversity of Calophyllum inophyllum L. oil bioactive components related to their specific geographical distribution in the South Pacific region. Peer J. 2019, 7, e6896. [CrossRef]

20. Perumal, S.S.; Ekambaram, S.P.; Dhanam, T. In vivo antiarthritic activitiy of the ethanol extracts of stem bark and seeds of Calophyllum inophyllum in Freund's complete adjuvant induced arthritis. Pharm. Biol. 2016, 55, 1330-1336. [CrossRef]

21. Alencar, J.; Gosset, G.; Rahmouni, H.; Culcasi, M.; Robin, M.; Reynier, J.-P.; Piccerelle, P.; Pietri, S. Development of spray- and freeze-dried high-concentration sesamol emulsions and antioxidant evaluation in fibroblasts and UV-exposed rat skin slices. Drug Dev. Res. 2008, 69, 251-266. [CrossRef]

22. Alencar, J.; Gosset, G.; Robin, M.; Pique, V.; Culcasi, M.; Clement, J.L.; Mercier, A.; Pietri, S. Improving the stability and antioxidant properties of sesame oil: Water-soluble spray-dried emulsions from new transesterified phenolic derivatives. J. Agric. Food Chem. 2009, 57, 7311-7323. [CrossRef] [PubMed]

23. Kandouli, C.; Cassien, M.; Mercier, A.; Delehedde, C.; Ricquebourg, E.; Stocker, P.; Mekaouche, M.; Leulmi, Z.; Mechakra, A.; Thétiot-Laurent, S.; et al. Antidiabetic, antioxidant and anti inflammatory properties of water and n-butanol soluble extracts from Saharian Anvillea radiata in high-fat-diet fed mice. J. Ethnopharmacol. 2017, 207, 251-267. [CrossRef] [PubMed]

24. Leu, T. Contribution à la Connaissance de la Flore Polynésienne: Évaluation de l'intérêt Pharmacologique de Quelques Plantes Médicinales et Étude Phytochimique du Tamanu (Calophyllum inophyllum L.—Clusiaceae). Ph.D. Thesis, Molecular Chemistry, Université de la Polynésie Française, Papeete, Tahiti, 15 May 2009.

25. Shen, Y.C.; Hung, M.C.; Wang, L.T.; Chen, C.Y. Inocalophyllins A, B and their methyl esters from the seeds of Calophyllum inophyllum. Chem. Pharm. Bull. 2003, 51, 802-806. [CrossRef] [PubMed]

26. Palmer, C.J.; Josephs, J.L. Synthesis of the Calophyllum coumarins. Part 2. J. Chem. Soc. Perkin Trans. 1995, 3135-3152. [CrossRef]

27. Galinis, D.L.; Fuller, R.W.; McKee, T.C.; Cardellina, J.H., II; Gulakowski, R.J.; McMahon, J.B.; Boyd, M.R. Structure-Activity Modifications of the HIV-1 Inhibitors (+)-Calanolide A and (-)-Calanolide B. J. Med. Chem. 1996, 39, 4507-4510. [CrossRef]

28. Zembower, D.E.; Liao, S.; Flavin, M.T.; Xu, Z.Q.; Stup, T.L.; Buckheit, R.W.; Khilevich, A.; Mar, A.A.; Sheinkman, A.K. Structural analogues of the calanolide anti-HIV agents. Modification of the trans-10,11-dimethyldihydropyran-12-ol ring (ring C). J. Med. Chem. 1997, 40, 1005-1017. [CrossRef] [PubMed]

29. McKee, T.C.; Cardellina, J.H., II; Dreyer, G.B.; Boyd, M.R. The pseudocalanolides: Structure revision of calanolides C and D. J. Nat. Prod. 1995, 58, 916-920. [CrossRef] [PubMed]

30. Cassien, M.; Petrocchi, C.; Thétiot-Laurent, S.; Robin, M.; Ricquebourg, E.; Kandouli, C.; Asteian, A.; Rockenbauer, A.; Mercier, A.; Culcasi, M.; et al. On the vasoprotective mechanisms underlying novel $\beta$-phosphorylated nitrones: Focus on free radical characterization, scavenging and NO-donation in a biological model of oxidative stress. Eur. J. Med. Chem. 2016, 119, 197-217. [CrossRef]

31. Patel, D.; Desai, S. Phytochemical screening, in vitro anti-microbial and anti-inflammatory activity of methanolic extract of aster lanceolatus willd leaves. Int. J. Med. Res. 2016, 1, 26-30.

32. Missiakas, D.M.; Schneewind, O. Growth and laboratory maintenance of Staphylococcus aureus. Curr. Protoc. Microbiol. 2013, 9 , 1-12. [CrossRef]

33. Culcasi, M.; Benameur, L.; Mercier, A.; Lucchesi, C.; Rahmouni, H.; Asteian, A.; Casano, G.; Botta, A.; Kovacic, H.; Pietri, S. EPR spin trapping evaluation of ROS production in human fibroblasts exposed to cerium oxide nanoparticles: Evidence for NADPH oxidase and mitochondrial stimulation. Chem. Biol. Interact. 2012, 199, 161-176. [CrossRef] [PubMed]

34. Wilkins, T.D.; Chalgren, S. Medium for use in antibiotic susceptibility testing of anaerobic bacteria. Antimicrob. Agents Chemother 1976, 10, 926-928. [CrossRef] [PubMed]

35. Prasad, D.; Ram, M.S.; Sawhney, R.C.; Ilavazhagan, G.; Banerjee, P.K. Mechanism of tert-butylhydroperoxide-induced cytotoxicity in U-937 macrophages by alteration of mitochondrial function and generation of ROS. Toxicol. In Vitro 2007, 21, 846-854. [CrossRef]

36. Culcasi, M.; Rockenbauer, A.; Mercier, A.; Clément, J.L.; Pietri, S. The line asymmetry of electron spin resonance spectra as a tool to determine the cis:trans ratio for spin-trapping adducts of chiral pyrrolines $N$-oxides: The mechanism of formation of 
hydroxyl radical adducts of EMPO, DEPMPO, and DIPPMPO in the ischemic-reperfused rat liver. Free Radic. Biol. Med. 2006, 40, 1524-1538. [CrossRef]

37. Duling, D.R. Simulation of multiple isotropic spin-trap EPR spectra. J. Magn. Reson. B 1994, 104, 105-110. [CrossRef]

38. Patil, A.D.; Freyer, A.J.; Eggleston, D.S.; Haltiwanger, R.C.; Bean, M.F.; Taylor, P.B.; Caranfa, M.J.; Breen, A.L.; Bartus, H.R.; Johnson, R.K.; et al. The inophyllums, novel inhibitors of HIV-1 reverse transcriptase isolated from the Malaysian tree, Calophyllum inophyllum Linn. J. Med. Chem. 1993, 36, 4131-4138. [CrossRef]

39. Laure, F.; Herbette, G.; Faure, R.; Bianchini, J.P.; Raharivelomanana, P.; Fogliani, B. Structures of new secofriedelane and friedelane acids from Calophyllum inophyllum of French Polynesia. Magn. Reson. Chem. 2005, 43, 65-68. [CrossRef]

40. Huerta-Reyes, M.; Basualdo, M.C.; Abe, F.; Jimenez-Estrada, M.; Soler, C.; Reyes-Chilpa, R. HIV-1 inhibitory compounds from Calophyllum brasiliense leaves. Biol. Pharm. Bull. 2004, 27, 1471-1475. [CrossRef]

41. Cavé, A.; Debrayn, M.; Henryn, G.; Kunesch, G.; Polonsky, J. Structure of a new 4-alkylcoumarin isolated from Calophyllum inophyllum. C. R. Séances Acad. Sci. C 1972, 275, 1105-1107.

42. Ito, C.; Itoigawa, M.; Mishina, Y.; Cechinel-Filho, V.; Enjo, F.; Tokuda, H.; Nishino, H.; Furukawa, H. Chemical constituents of Calophyllum brasiliensis. 2. Structure of three new coumarins and cancer chemopreventive activity of 4-substituted coumarins. J. Nat. Prod. 2003, 66, 368-371. [CrossRef]

43. Ma, T.; Gao, Q.; Chen, Z.; Wang, L.; Liu, G. Chemical resolution of $( \pm)$-calanolide A, $( \pm)$-cortalide A and their 11-demethyl analogues. Bioorg. Med. Chem. Lett. 2008, 18, 1079-1083. [CrossRef] [PubMed]

44. Khilevich, A.; Mar, A.; Flavin, M.T.; Rizzo, J.D.; Lin, L.; Dzekhtser, S.; Brankovic, D.; Zhang, H.; Chen, W.; Liao, S.; et al. Synthesis of (+)-calanolide A, an anti-HIV agent, via enzyme catalysed resolution of the aldol products. Tetrahedron Asymmetry 1996, 7, 3315-3326. [CrossRef]

45. Joshi, S.P.; Thengane, S.R. Calophyllum austroindicum: A new source of calanolide A. J. Med. Arom. Plant Sci. 2010, $32,193-195$.

46. Seneviratne, K.N.; Kotuwegedara, R.T. Antioxidant activities of the phenolic extracts of seed oils and seed hulls of five plant species. Food Sci. Tech. Int. 2009, 15, 419-425. [CrossRef]

47. Kartika, I.A.; Cerny, M.; Vandenbossche, V.; Rigal, L.; Sablayrolles, C.; Vialle, C.; Suparno, O.; Ariono, D.; Evon, P. Direct calophyllum oil extraction and resin separation with a binary solvent of $n$-hexane and methanol mixture. Fuel 2018, 221, 159-164. [CrossRef]

48. Pẹkal, A.; Pyrzynska, K. Evaluation of aluminium complexation reaction for flavonoid content assay. Food Anal. Methods 2014, 7 , 1776-1782. [CrossRef]

49. Cos, P.; Ying, L.; Calomme, M.; Hu, J.P.; Cimanga, K.; Van Poel, B.; Pieters, L.; Vlietinck, A.J.; Vanden Berghe, D. Structure-activity relationship and classification of flavonoids as inhibitors of xanthine oxidase and superoxide scavengers. J. Nat. Prod. 1998, 61, 71-76. [CrossRef]

50. Ambigaipalan, P.; de Camargo, A.C.; Shahidi, F. Phenolic compounds of pomegranate byproducts (outer skin, mesocarp, divider membrane) and their antioxidant activities. J. Agric. Food Chem. 2016, 64, 6584-6604. [CrossRef]

51. Ribeiro, D.; Freitas, M.; Tomé, S.M.; Silva, A.M.S.; Porto, G.; Cabrita, E.J.; Marques, M.M.B.; Fernandes, E. Inhibition of LOX by flavonoids: A structure-activity relationship study. Eur. J. Med. Chem. 2016, 72, 137-145. [CrossRef]

52. Aminudin, N.I.; Ahmad, F.; Taher, M.; Zulkifli, R.M. $\alpha$-Glucosidase and 15-Lipoxygenase inhibitory activities of phytochemicals from Calophyllum symingtonianum. Nat. Prod. Commun. 2015, 10, 1585-1587. [CrossRef]

53. Traykova, M.; Kostova, I. Coumarin derivatives and oxidative stress. Int. J. Pharmacol. 2005, 1, 29-32. [CrossRef]

54. Rodriguez, R.J.; Miranda, C.L.; Stevens, J.F.; Deinzer, M.L.; Buhler, D.R. Influence of prenylated and non-prenylated flavonoids on liver microsomal lipid peroxidation and oxidative injury in rat hepatocytes. Food Chem. Toxicol. 2001, 39, 437-445. [CrossRef]

55. Foti, J.J.; Devadoss, B.; Winkler, J.A.; Collins, J.J.; Walker, G.C. Oxidation of the guanine nucleotide pool underlies cell death by bactericidal antibiotics. Science 2012, 336, 315-319. [CrossRef] [PubMed]

56. De Souza, S.M.; Delle Monache, F.; Smânia, A., Jr. Antibacterial activity of coumarins. Z. Naturforsch. 2005, 60, 693-700. [CrossRef] [PubMed]

57. Kayser, O.; Kolodziej, H. Antibacterial activity of simple coumarins: Structural requirements for biological activity. Z. Naturforsch. 1999, 54c, 169-174. [CrossRef] [PubMed]

58. Mora-Pale, M.; Bhan, N.; Masuko, S.; James, P.; Wood, J.; McCallum, S.; Linhardt, R.J.; Dordick, J.S.; Koffas, M.A. Antimicrobial mechanism of resveratrol-trans-dihydrodimer produced from peroxidase-catalyzed oxidation of resveratrol. Biotechnol. Bioeng. 2015, 112, 2417-2428. [CrossRef]

59. Zengin, G.; Ceylan, R.; Katanić, J.; Mollica, A.; Aktumsek, A.; Boroja, T.; Matić, S.; Mihailović, V.; Stanić, S.; Aumeeruddy-Elalfi, Z.; et al. Combining in vitro, in vivo and in silico approaches to evaluate nutraceutical potentials and chemical fingerprints of Moltkia aurea and Moltkia coerulea. Food Chem. Toxicol. 2017, 107, 540-553. [CrossRef]

60. De Freitas Araújo, M.G.; Hilário, F.; Vilegas, W.; dos Santos, L.C.; Brunetti, I.L.; Sotomayor, C.E.; Bauab, T.M. Correlation among antioxidant, antimicrobial, hemolytic, and antiproliferative properties of Leiothrix spiralis leaves extract. Int. J. Mol. Sci. 2012, 13, 9260-9277. [CrossRef]

61. Wlaschek, M.; Scharffetter-Kochanek, K. Oxidative stress in chronic venous leg ulcers. Wound Repair Regen. 2005, 13, 452-461. [CrossRef]

62. Schäfer, M.; Werner, S. Oxidative stress in normal and impaired wound repair. Pharmacol. Res. 2008, 58, 165-171. [CrossRef] 